\title{
Mutual Relations of Macroeconomic Balances - Conclusions From International Comparisons
}

\author{
Jerzy Żyżýnski*
}

We are still witnessing many misconceptions stemming from misunderstanding of macroeconomic conditions upon which macroeconomic stability relies. The economy is a complex mechanism consisting of great many communicating vessels between which the income and expenditure of a variety of entities are flowing. According to the most synthetic macroeconomic approach, in the case of an open economy, such flows make an arrangement of three macroeconomic balances which are interrelated by the following equation, discussed hundreds of times in macroeconomic literature: $(G-T)=(S-I)+(Z-X)$. The very essence of the conditions of the macroeconomic stability is an interdependence between these balances, which are achieved as the economy operates. The author discusses the effects of promoting the myth of the budget balance, the understanding of the budget deficit and public debt, the importance of the interpretation of savings and investment, the importance of the balance as a distribution and resources, the relationship between the size of M2 money and the relationship between market rate and price resulting from purchasing power parities. He has undertaken a statistical analysis of the relationships between three macroeconomic balances on the basis of data for 35 countries in the years 2000-2015. The conclusions confirm the illusory nature of certain media-grounded views.

Keywords: macroeconomic stability, national savings, national investments, current accounts, OECD countries.

Submitted: 03.06.18 | Accepted: 11.12.18

\section{Wzajemne relacje bilansów makroekonomicznych - wnioski z porównań międzynarodowych}

$W$ sferze medialnej $i w$ dyskursach polityków wciąż jesteśmy świadkami nieporozumień wynikających z niezrozumienia makroekonomicznych warunków, od których zależy stabilność makroekonomiczna. Gospodarka to złożony mechanizm naczyń połaczonych, którymi przeptywaja dochody $i$ wydatki rozmaitych podmiotów. W najbardziej syntetycznym makroekonomicznym ujeciu w przypadku gospodarki otwartej przeptywy te tworza uktad trzech makroekonomicznych bilansów, które taczy następujące - wielokrotnie omawiane w literaturze makroekonomicznejrównanie: $(G-T)=(S-I)+(Z-X)$. Istota analizowanych warunków makroekonomicznej stabilności sa wzajemne relacje między tymi bilansami, które kształtuja się $w$ procesie funkcjonowania gospodarki. Autor dyskutuje skutki propagowania mitu równowagi budżetowej, rozumienie deficytu budżetowego $i$ dtugu publicznego, znaczenie interpretacji oszczędności i inwestycji, znaczenie bilansu handlowego i rachunku bieżącego, znaczenie wielkości agregatu

\footnotetext{
* Jerzy Żyżyński - prof. dr hab., Faculty of Management, University of Warsaw. https://orcid.org/00000001-8904-8665.

Correspondence address: Faculty of Management, University of Warsaw, ul. Szturmowa 1/3, 02-678 Warszawa; e-mail: zyzynski@wz.uw.edu.pl.
} 
pieniężnego M2 oraz zwiazki między rynkowym kursem a kursem wynikajacym z parytetu sity nabywczej. Autor przeprowadzit statystyczna analizę zwiazków między bilansami makroekonomicznymi na bazie danych dla 35 krajów w okresie lat 2000-2016. Wnioski z tej analizy potwierdzaja iluzoryczność ugruntowanych medialnie pogląów.

Słowa kluczowe: stabilność makroekonomiczna, bilanse makroekonomiczne, krajowe oszczędności, krajowe inwestycje, rachunek bieżący, kraje OECD.

Nadesłany: 03.06.18 | Zaakceptowany do druku: 11.12.18

JEL: A100, E100, E190, E600

The process of Europe overcoming the crisis - which at last may be considered practically successful these days - is much favored by rejection of schematic attitudes and by being open to unconventional instruments of monetary policy as revealed by the European Central Bank. At the same time, the rigors of fiscal policy seem alleviated as the issues of fiscal stabilization appear to become somewhat less prioritized, due to scarce efficacy of the so-called fiscal pact. Crucial decisions are inspired by guidelines of macroprudential policy whose scope is to safeguard financial stability conceived as a "state in which no accumulation of systemic risk occurs. Systemic risk might be defined as a threat that the process of provision of necessary products and financial services by the financial system would undergo such turbulence that a serious undermining of the economic growth becomes likely, causing a downfall in the level of welfare in the society." (ECB, 2019).

Nonetheless, we are still witnessing many misconceptions pervading the field of media and political discourse, and stemming from misunderstanding of macroeconomic conditions upon which that stability relies. The very essence of such conditions is an interdependence of the fundamental macroeconomic balances which are achieved as the economy operates. It is from the economy and how sound it is that the state of individual balances, and most of all the state of public finance, results. The scope of this article is to reveal these mutual relations and interdependences, using the OECD member states as an example. However, considering how underrated the significance of mutual relations between macroeconomic balances is, we shall start with putting some clarity into a number of basic notions.

\section{Macroeconomic Balances}

It would be a cliché to argue that the economy is a complex mechanism consisting of great many communicating vessels between which the income and expenditure of a variety of entities are flowing. According to the most synthetic macroeconomic approach, in the case of an open economy such flows make an arrangement of three macroeconomic balances which are interrelated by the following equation, discussed hundreds of times in macroeconomic literature:

$$
(\mathrm{G}-\mathrm{T})=(\mathrm{S}-\mathrm{I})+(\mathrm{Z}-\mathrm{X}),
$$

where $(\mathrm{G}-\mathrm{T})$ is the deficit of the balance of the state budget (public sector) - its expenditure $G$ minus its income T; a positive value of that difference signifies a deficit, while a negative one expresses a budget surplus; $(\mathrm{S}-\mathrm{I})$ is a surplus of the balance of savings and investments of the private sector, i.e. households and undertakings which save $\mathrm{S}$ and invest I. Finally, $(\mathrm{Z}-\mathrm{X})$ is a deficit of the balance of current account which results from comparing the outlays made on import $\mathrm{Z}$ with the income earned on export $X$; a positive value of that difference signifies a negative balance of foreign trade, and as we take account of other monetary flows related with transfers of income, dividends and all sorts of payments, we obtain a deficit on the current account.

This equation has crucial importance for understanding the fundamental relationships which determine macroeconomic equilibrium (Żyżyński, 2009, pp. 46-53). If $(\mathrm{G}-\mathrm{T})$ results positive, this tells us that the state budget deficit equals the surplus of savings over the investments of the private sector, increased by the value of defi- 
cit in foreign trade exchange, expressed in domestic currency.

That may be considered as the effect of the budgetary deficit being compensated, balanced or financed by:

- a surplus of savings over the investments - i.e. by what remained after only partial transformation of savings into the investments (investment credits); and, additionally, by:

- funds used to finance the surplus of import over the export - they are sourced from foreign investments in our country's treasury bonds which provide enough money in foreign currencies to cover the surplus of import over the export; the same foreign funds may also be used to increase the country's foreign exchange reserves - the practice which is then reflected in such country's balance of payments as an increase in official reserve assets.

In the variant expressed with the equation (1), we find an explanation of relations which determine the budgetary deficit. These may also be presented another way:

$$
(\mathrm{T}-\mathrm{G})=(\mathrm{I}-\mathrm{S})+(\mathrm{X}-\mathrm{Z}) .
$$

In this formula (which we are going to examine in practice in the final part of this study) the equation says that the outcome of the budget is balanced by a surplus of investments compared to savings, as well as by the outcome of the current account

Accordingly, we shall define this equation (in either former or latter variant) as the equation of the equilibrium of macroeconomic balances. Whereas in mathematic terms it is trivial, in macroeconomic ones it actually provides an aggregated reflection of complex dependences; dependences that are quite intricate because there is no simple and unilateral reason-effect relation occurring between its elements. The equation is really an identity $^{1}$ which means that the result of one process impacts other ones, but the results of other processes influence the original one just as well.

\section{Institutional Circumstances}

As its background, each of these balances has an arrangement of institutions the role of which is to carry out and manage the processes that result in this or another condition of the balance, represented by a difference shown in the equation in brackets. Therefore, the balance of the budget the result of which is $(\mathrm{G}-\mathrm{T})$ is achieved by institutions forming the state central government (central budget is resolved by the parliament via the Budgetary Act) as well as its local governments (local budgets adopted by bodies of territorial administration), jointly responsible for the budget of the public finance sector.

Then, the balance of the budget the result of which is $(\mathrm{S}-\mathrm{I})$ is taken care of by financial institutions, mainly banks, which collect savings $\mathrm{S}$ from the so-called surplus units of the private sector and transfer the funds thus acquired to the so-called deficit units, i.e. those in need of more money than they manage to earn in the course of their activities. The funds transferred create the stream I of the investment credits extended as well as other forms of crediting. One specificity of these institutions is that they are partially able to generate money themselves, as an effect of which the savings $\mathrm{S}$ are not an essential condition of carrying out the investments I. As observed by J.M. Keynes and independently by Michał Kalecki, it is not savings that generate the investments; instead, the opposite holds true: the investments, whose level depends on a propensity to invest, are the source of both income and savings, in line with the propensity to save, formed in some particular circumstances. Furthermore, there are other non-banking financial institutions through which the surplus of funds making the savings is transferred to the economy as the investments. However, some portion of the funds these institutions use (a stock exchange being a good example) is derived from saving deposits put in the banks. Those who acquire securities in secondary trading in the stock exchange simply change a form of their property from that of bank deposit to that of stock, potentially more profitable but also bearing a higher risk, or to that of bonds which bear low risk. Some purchasers, acting indirectly through expert financial institutions, acquire securities from primary issues: the base for such transactions and - to put it this way - the base for the financial system are bank deposits creating the "secondary layer" of the M2 monetary aggregate.

The third balance whose result, according to the approach (1), is defined by the 
difference $(Z-X)$, i.e. the difference between the outlays for import $\mathrm{Z}$ and the income earned on export $\mathrm{X}$, is generated by the community of undertakings participating in foreign exchange. Some of them are involved in export, the result of which is an inflow of foreign currencies to the country, then deposited within the banking system. Other ones, or sometimes the same ones, operate in import and to that end they withdraw an adequate quantity of foreign assets from the banks and spend them to purchase commodities or services abroad. One thing which is especially important and yet sometimes overlooked is that the actual value of components of that balance as well as its result, i.e. the difference between import and export (where it is positive, we speak about a trade exchange deficit), and its relation to the other balances, depend on the exchange rate, i.e. on the market value of foreign currencies used in international exchange.

Some issues related with these institutional circumstances are shortly discussed below.

\section{The Mythology of the Budgetary Equilibrium}

There have been a great deal of myths accruing around these balances, which circulate in the so-called "media sphere", becoming an element of erroneous perception of economic issues among many columnists or politicians dealing with economy. Worse still, it is not uncommon for professional economists to fall in the trap of some of these myths or misunderstandings. Such myths include what has become a sort of a modern times' slogan - the belief, reiterated day after day, that "one must not burden the state with debt at the cost of future generations". That kind of "legend of budgetary equilibrium" rooted deep in the social awareness and became a serious element of common disinformation and disorientation about economic issues. The problem is that its proponents fail to see the institutional circumstances and relations with other balances, often with quite serious economic consequences. Therefore, it seems pertinent to explain the economic role of deficit and debt, seen as the effect of maintaining debt in the long run.

Above all, it should be reminded that debt is a natural, essential and necessary element of market economy as it applies money as an instrument of exchange. Some time ago I suggested defining money as "the right to acquire goods and services". That "right" keeps circulating in the economy as a sort of "fuel" driving its gears: we receive it in exchange for something we give to the society - most of all, our labor. As we purchase anything, for example goods and services generated by others, or perhaps some components of our property (assets), we pass that right over, further on. People work hard to get as much of that right as they manage to, but they also fight for it, sometimes they steal it or even go as far as kill to get it, thus trespassing the borderline of crime. We also postpone that "right" in order to use it later in the future - in other words we make savings and what we are not using right away becomes deposited in the bank so that others may lend it with a promise they would give it back. This is how debt arises.

The essential nature of indebtedness results from the fact that where some people make savings ${ }^{2}$, i.e. renounce immediate use of some part of the rights they have to purchase goods and services, then there have to be other ones who take these rights over, take credit and make use of means the first ones deposited - the process which inevitably leads to emergence of debt. In more specific terms, one of entities participating as a party in that process in the role of borrower may be - or even must be, for that matter - the State, as its role stems, among other things, from relations between macroeconomic balances.

\section{Savings and Investments}

However, the economic role of saving in economic mechanisms is not simple. While in economy columns of newspapers or in declarations and addresses of politicians, saving is highly recommended as a praiseworthy attitude fostering economic growth, it is quite easy to see that as such, the act of saving leads to some inconsistence, or even a sort of fracture in the very structure of the economic system. This is because savings make an unspent portion of the income earned by undertakings and households in other words, they are means put aside. Therefore, this translates into a situation where people as a community fail to buy some part of what they generated. Should 
the entire process be restricted to the sole act of saving, then we would have to deal with an imbalance resulting from the fact that commercial entities, seen as a community, have borne costs of wages, however without being able to regain through transactions of sale the outlays they made because potential buyers withheld their purchasing decisions. In effect, the entrepreneurs have to increase their stock, bearing further costs of its maintenance, but still cannot get their money back. This has to cause payment gridlocks to the point where a chain of unserved obligations begins to strangle the economy.

The system can be restored to balance and regain its consistence only once the means saved - in other words, postponed rights to purchase goods and services - are channeled back to the economy through crediting activities of banks. Accordingly, some people's propensity to save has to be compensated by other people's eagerness to take credits, i.e. to borrow and run into debts. This is the concept of essential and natural status of debt in any moneybased economy: if certain people save money, there have to be others who borrow money by taking credits and making debts. We shall see further on how significant consequences stem from the fact that an alternative way to restore consistency to the economy is to export the goods which remained unsold in the domestic market due to a deficit of purchasing power resulting from the propensity to make savings.

Thus, we have to deal with two interrelated processes, of saving and of investing, which are driven by some people's propensity to save and other people's propensity to invest - psychological motivations determining behaviors of entities in capitalist economy that are crucial for healthy economic dynamics. Acting as stimulating factors for these attitudes is not only information about business outlooks, interest rates or fiscal incentives, but also - or perhaps mainly - patterns and habits rooted in cultural standards and traditions of the society.

In this approach savings $S$ are a stream category: they constitute an outflow of funds which is torn apart from the stream ${ }^{3}$ of income like in a river delta as it runs out to the sea, and transformed, by the financial system, into the stream of investments I. The very nature of investments is that they entail effects in terms of resources and property - effects recorded in balances of the entities that participate in the process. ${ }^{4}$

In consequence, we should notice some misunderstandings concerning the difference between saving and investing. It is wrong to only reduce that difference to the issue of a level of risk ${ }^{5}$. In fact, it is hard to deny that "in saving (and with financial instruments related to saving) the risk is relatively low, while at investing it may be much higher (the risk of never seeing the profit expected, the risk of losing the capital invested or, in extreme cases, even the risk of losses exceeding the capital invested)" 6 . However, the essence of the difference between these notions is in the economic role they play: whether deposited means passively rest as liabilities of financial institutions, with cash occurring on the respective side of assets, or whether they work within such institutions' assets, generating income for the entities which have absorbed them and, eventually, generating income earned by other entities - those for which the funds were spent in the first place.

Seen this way, savings do not generate demand; instead, they are renouncement of immediate money spending. On the part of one who saves, they are suspension of demand - in fact temporary, but for an indefinite time because it remains unknown when the means earned by that person would finally return to the economy in the form of expenses to become, in turn, the income earned by other entities, etc. Investments, on the other hand, constitute one of forms of prompt and immediate return of saved means to the economy; they generate demand for investment goods and, secondarily for consumer goods - as an effect of increasing income of producers of the investment goods. It is clear, after all, that thanks to them, to the fact they save money and deposit their income in banks, the mechanism of money multiplier works, so that the means saved are then multiplied in the chain of credits, incomes and acts of saving.

The interplay of the two elements of the process - saving and investing - is easier to understand as we look upon effects they entail in booking records. Namely, they lead to formation of a peculiar chain of interrelated records in balances. Over the 
first stage, savings which form the assets of saving entities become liabilities of institutions involved in financial agency, mainly banks. On the opposite side of the banks' balances they are then directly recorded as assets in cash, i.e. means which yield no income, being passive assets ${ }^{7}$. Therefore, as these funds are not working, it seems right to say that the saver's assets turned into liabilities - the bank's liabilities, for that matter - and thus the "rights to acquire goods and services have become frozen". Increased liabilities form a basis for a situation where, as far as possible - and possibilities here stem from the entities' propensity to save and their eagerness to also use other party's means, which is shaped by current condition of business outlooks - they gradually become activated through the banks' crediting activities. The funds the banks are unable to invest in the economy make their over-liquidity which may either be made available to other banks on the interbank market or is absorbed by the central bank.

The propensity to save has crucial importance in that process. It is determined by a number of factors, including, most of all, general economic conditions, but fiscal incentives are also crucially important in this respect. Therefore, it seems worth emphasizing here that one of underrated causes prompting the actors of the process to reach for foreign assets, i.e. to activate idle assets passively resting in the financial system as savings, is to apply the so-called tax shield (Czekaj \& Dresler, 2005). This practice is used by businesses in order to get a shield, i.e. protection against taxes, understood as a reduction of their income tax. This is a sort of "escaping taxes" through financing one's activity using somebody else's capital, especially credit. The condition here is that undertakings applying the tax shield are subject, upon general rules, to taxation with income tax the structure of which provides for investment-favoring tax reliefs. This enables them to classify their financial costs (i.e. interest on credit, appreciation and the outlays made on leasing) as tax deductibles (costs of earning income) thus decreasing their tax burden. The tax incentive here acts as a sort of signal sent by tax authorities, meant to provoke an appropriate answer - some desired action. The signal is as follows: "You are obliged to give back a sizable portion of your income (your value-added) for public purposes, but you are allowed to give back less if you invest by using credit". As is quite easy to see, the signal achieves its effect where taxes are high enough and structured the right way, i.e. they include appropriate tax incentives. In that case taxes increase demand for credit, whereas low taxes translate into businesses having stronger motivation to develop their own savings out of profits set aside and to fund their activity out of their own resources - a practice which, by the way, is not always recorded in statistics as investments ${ }^{8}$. Moreover, as can easily be observed, this mechanism of businesses financing themselves with their own savings also acts to suffocate wages, because facing a stronger motivation to fund their activity out of their own means, undertakings endeavor to increase them, also by reducing other costs, including those spent on labor.

Let us grasp the difference between both mechanisms. Where a business uses its own means, we deal with withdrawal of deposits. During an early stage of the process the balances of banks decrease and deposits withdrawn as a result of businesses directly financing the investments they make turn into revenues of companies which generate respective means of investment, for example carrying out services (in the field of construction and other) for the investing entity, etc. In this context it should be remembered that Poland experiences a low level of money resources in relation to GDP (as discussed further on), but also low wages. At present, as we hear complaints about the lack of investments, we are also facing an evident decrease of the level of deposits businesses keep in banks.

Where, on the other hand, a company funds its activities with credit, assets deposited by both households and businesses become activated by a bank and become revenue of a borrower and then an income of whoever supplied that borrower with services, goods etc. In other words, money multiplicator keeps working, balances of banks increase, the pool of M2 money grows. Savings deposited in the bank turn into the operating part of the bank assets so they yield income thereto. Funds activated in the form of investment credits find their way to borrowers and, in turn, become recorded in their balances as lia- 
bilities towards the bank. Initially, these are banks' assets in the form of cash passively resting on their account or in their coffers, used by the borrower to carry out his payments as he pays wages to his employees or pays his contractors for products or services acquired. As a result, unspent, saved funds become channeled back to the economy, making income of employees and entrepreneurs both of companies which fund their activity with credit and of their contractors. This way, the manner in which funds are used means that the future generating capacities of the investing entities strengthen, thus translating into new potential for the GDP growth. However, rather importantly, as a result new income is generated which is then spent or saved according to the saving propensity shaped over that period - in other words, the phenomenon described by J.M. Keynes occurs: investments become a source of savings.

At the same time, an obligation toward the bank entails creation of debt. It is here that we get the concept of inevitability of debt as a consequence of saving: technically, debt arises with the borrower, but after all the funds deposited in the bank also constitute the bank's debt toward the depositor. As we see, the debt makes quite a natural element of the economy which uses money.

What is of particular importance is that as the effect of the process, credits not only increase the property and the potential for profits to grow, but they eventually become a source of income as well, thanks to which demand is transferred from savers to borrowers. Indeed, the demand partially changes its structure from consumer goods which prevail in total demand into investment goods, but still, in general, thanks to investments money comes back to the economy, undertakings enjoy compensated costs and generate profits, payment gridlocks are smoothened and the economy as the whole is reverted to the state of equilibrium.

In the classic model of economy, however, as a condition for this to happen, the $\mathrm{S}=\mathrm{I}$ state of balance has to be achieved - in other words, the right of Say has to be fulfilled. Thanks to Keynes (and Kalecki) we know, though, that this condition usually remains unsatisfied as this would require equaling the propensity to save (mainly on the part of households which make for the principal net lenders) with that to invest (mainly on the part of entrepreneurs). In practice, these two tendencies rarely match, usually the former one is stronger than the latter, causing $\mathrm{S}>\mathrm{I}$ inequality. As a consequence, a problem arises which - as we shall see further on - is solved by the State through its need to finance the deficit.

\section{The Impact Upon the Pool of Money and Non-Banking Financial Institutions}

As discussed above, thanks to activation of the sums saved, savings work - and this is exactly what we regard as investments. We have shown that the economic process which occurs here has a stream nature: namely, a stream of savings becomes torn apart from the stream of income and transformed into a stream of investments which, in turn, become a stream of income. One aspect that is of particular importance here and yet is somehow misunderstood by many journalists dealing with economics is that the resources saved, reflected in the banks' liabilities, are at the same time accumulated - they make a pool of deposits contributing to creation of the total pool of monetary resources - the second layer of the M2 monetary aggregate. The presence of this pool at an adequate level is of fundamental importance for modern economy, because the finance and the efficacy with which the system of monetary circulation works, the rights to acquire goods and services, determine the way the system operates as a whole. The pool - the one I once called "the capital leg" of the monetary aggregate $^{9}-$ as it changes its structure and transforms from cash and deposits into other forms of assets, in particular capital market securities, becomes the driving force of the economy.

Considering this, it should be observed that in Poland, as of July 201710 , the value of deposits kept in the banks by households amounted to PLN 712 billion, however, as much as $60 \%$ of it (PLN 427 bn) were current deposits, classified as M1 money. Admittedly, for our macroeconomic model, particular "localization" of deposits by banks is not really significant: the deferred consumption constituting $\mathrm{S}$ includes both deposits kept on current accounts and fixed-term deposits ${ }^{11}$. More specifically, deposits kept by non-financial undertak- 
ings achieve the level of PLN 247 billion - although these mainly consist of current deposits, as undertakings are rather unlikely to keep their assets on fixed-term bank accounts; in total, the sum of current deposits amounts to PLN 659 bn. However, a really stable fundament for activation of the funds saved is provided by fixedterm assets which constitute that "capital leg" of the economy. Their sum was only PLN 415 bn which, added to M1 money (PLN 837 bn in the form of money in circulation and current deposits), constituted M2 money in the amount of PLN 1253 bn. Accordingly, the capital leg in question occurs rather brittle: in Poland the relation of M3 money ${ }^{12}$ to the GDP, in 2016, accounted for $68.4 \%$, compared to $106 \%$ in the Eurozone and the global average at $116 \%$. To quote some more comparison, in the Czech Republic the same accounted for $80 \%$, and in Slovakia for $70 \%$. At the same time, M1 money in Poland is $44 \%$ of GDP, against $67 \%$ in the Eurozone (higher by half, as we see), respective percentages for the Czech Republic and Slovakia being $72 \%$ and $54 \%$. In consequence, the potential of banks in Poland on the active side is mediocre at best. Banks' total liabilities to domestic entities amounted to PLN 1162 billion, including PLN 672 bn to households and PLN 329 bn to the corporate sector - in which only PLN 175 billion in investment credits. As we see, actual activation of savings was mainly directed to meeting the needs of households. Accordingly, one could argue that savings of households were largely reverted thereto, understood as a community, in the form of consumer credits (PLN 171 bn) and housing credits (PLN 390 bn).

It should be emphasized that while the figures quoted here reflect a state of the banks' balances, which results from deposit and credit transactions made over a number of years, and the resulting monetary aggregate (hence, these data relate to resources), still we get an indication that, from the stream-wise perspective, there also has to be quite an evident trend toward an advantage of savings $\mathrm{S}$ over investments I - which is going to be confirmed by a macroeconomic analysis.

Let us observe that investments actually constitute a sort of "proper activation" of funds set aside by a banking institution. As a matter of fact, whoever decides to defer spending some of his income may always save money in a passive way, by placing the assets in a bank deposit. However, there is an alternative and this is to entrust the money to other financial institutions, such as investment funds. In the latter case the saver's assets are recorded as liabilities by the fund chosen and become activated in the scope of its investment activities, in a manner depending on the funds specialty. We should observe here that the role of agency, played by a financial institution, is not really necessary. The practice of saving may also assume an active nature directly, where a saver acquires financial assets on his own - for example, by purchasing bonds (especially treasury bonds). In such a case we say that the saver "deposited" his savings or "put them in deposit" in bonds and in this meaning the word "deposit" includes and signifies both saving and investing aspects. Sure enough, such an operation results in the act of purchase of bonds being recorded on the liabilities side of their issuer - it is going to become part of foreign capital and then the assets in question are directly activated under the issuer's business activity.

In effect, we deal with a situation mentioned before. In the accountancy books, the chain of records is the same as it is in banks: the saver's funds are his assets; once entrusted to a financial institution they are recorded in its liabilities and in its assets, first as cash - and where they remain in cash, they constitute an over-liquidity that rests passively. Where, however, they are activated by the financial institution by handing them over further on by a credit extended or in the form of bonds or other financial instruments acquired (which are also called "active assets", unlike passive assets), an investment takes place. An investment may also take the form of direct spending of the funds entrusted by the issuer of respective financial instruments. The risk occurs on various links of the chain and depends on a particular nature of the institution involved, on the type of the financial instrument in question as well as on many other factors. The above-quoted simple interpretation of the difference between savings and investments according to their respective levels of risk is a great simplification and this is rather euphemistic to say so.

Accordingly, it is wrong to repeat the statement, popular among non-experts, 
that "for the economy, savings are the fuel that drives the economic growth". On the contrary, savings are the braking pedal for the economy while investments are the accelerator.

\section{The True Sense of Investments}

There is, however, yet another rather significant issue here: which is the real nature of this activation of deposited funds. This is quite important because not every act of acquiring some assets, one that the acquirer reckons to be an investment (so that investment it is, subjectively and in microeconomic sense), really constitutes an investment in the macroeconomic sense, understood as an operation which contributes to creation of the aggregate I in our equation. If, for example, a person gets involved in a transaction made in the secondary market (it should be remembered that the stock exchange is the secondary market of stock), e.g. purchasing shares from somebody else who sells them out of the need for cash to make some expenses, then direct savings directly turn into consumer expenses of that person who sold the shares.

In such a case the above-formulated criterion is met, according to which savings are distinguished from investments: the money saved, which was paid to the seller in exchange for shares sold, and was used to pay for the latter one's consumer expenses, was thus reverted to the economy and initiated a chain of further payments. However, an investment in the macroeconomic sense - or a "real investment" - only occurs when we deal with giving an investment credit or with a purchase of stock or bonds on the primary market, where either a borrower or an issuer of instruments in the capital market makes use of the funds obtained to increase the fixed assets, to modernize them, to purchase machinery and equipment, and so on. In other words, when such operations result in a growth of production and income in the future or in an extension of fixed assets. It is this kind of investments that generates new resources. This way, property values emerge in the real sphere, fostering development, while the investments made in securities in the secondary market, especially where they have a speculative nature, do not generate any tangible property and are only money transfers - transfers of rights to acquire goods and services between actors of a "financial game".

The investments in proper macroeconomic sense, then, are investments which, apart from effects in the area of consumption, also entail relatively durable real effects in terms of property - only the latter providing the real drive for the economy, becoming the fuel for its growth. If, for example, somebody undertakes to build a house on his own, then $\mathrm{S}$ represents his renouncement of current consumption and I represents his expenses made on materials needed for the project and on wages paid to the workers employed. In such a case we deal with a direct transfer of funds: any sums the investor did not spend on his consumption-related needs are then spent by producers of construction materials, masons, carpenters, floor-layers, plumbers, electricians etc. New income, generated thanks to the investments, feed the stream of consumer outlays, possibly with banks involved in intermediary roles.

It should also be observed that for a macroeconomic model, one which only analyzes the streams of money flows, a particular manner in which funds activated by financial institutions are used, or any individual methods of investing, are basically ignored as irrelevant. What really matters is what is recorded in the books and the fact that unspent money is channeled back to the economy because once the financial institutions activated it, somebody spent it, somebody else earned it etc., thus keeping the economy gears in motion. If nothing was built in the process, and no additional machinery was involved, only the effect of consumption occurred (banks activate funds also by giving consumer credits). The model does not really registers this, but in fact we end up just with low investment efficiency and low value of the investment multiplier.

\section{The State as the Balancing Factor - The Role of Deficit}

The most important thing for the economy is that if a surplus of unused means emerged in the financial system, causing the $\mathrm{S}>\mathrm{I}$ inequality, then the State plays the role of the actor of macroeconomic game who balances the system through the issuance of treasury bonds. By selling 
its bonds, the State takes over a part of rights to acquire goods and services which remained unused as a result of saving and returns it to the economy by funding some part of its expenditure. For their buyers, the bonds simply represent a form of investing, with little rate of return but good safety. However, the very existence of treasury bonds - and the existence of deficit, therefore - is very significant for the economy and that point is not, unfortunately, understood well enough by broad public and many actors of "public life".

If we ignore relations of the economy with the outside world, regarding it as a closed circuit, the equation (1) is reduced to just two following elements:

$$
(\mathrm{G}-\mathrm{T})=(\mathrm{S}-\mathrm{I})
$$

where: S - stream of savings; I - stream of investments; G - budgetary outlays; $\mathrm{T}$ - budgetary revenues.

The lack of understanding of the balancing nature of deficit determines its bad opinion, with many journalists and politicians going as far as to demand to eradicate the deficit altogether. Here, however, the issue of equilibrating the macroeconomic balances is not the only important aspect. Another aspect which is very significant and yet much underrated is that a budgetary deficit enables the State to implement its tasks at lower tax-related costs. Many people are unaware that macroeconomic taxes do not burden the society as a whole. In fact, they are only a transfer of purchasing power between various members of the society - by the way, in much the same way as is the case with any act of purchase of goods or services ${ }^{13}$. By paying taxes, therefore, just like when buying anything, we generate income, we provide remuneration, in this case to those employed in the public sector. Seen this way, taxes are just a transfer of income within the society, although, of course, for individual entities they represent cost ${ }^{14}$. Thanks to the fact that the State has a deficit, that individual cost is lower, by acquiring revenues through the sale of its treasury bonds, the State transfers a portion of income which is set aside as savings: it does it by borrowing it.

Then, it is quite obvious that to accept a deficit and to apply borrowing instruments - bonds in this case ${ }^{15}$ - to fund this deficit not only reduces tax-related costs but implies costs as well: after all, interest has to be paid on the debt, thus burdening the budgetary outlays and decreasing the State's potential to implement its tasks. An acceptable level of deficit depends on the level of these costs, and being more specific, on their relation to deficit: the difference between the deficit and the costs of debt servicing is known as the primary deficit. Where the costs of debt servicing account for a relatively insignificant part of the budgetary outlays, being lower than the deficit, so that the primary deficit is positive, the deficit also enables the State to implement some extra tasks. Where, on the other hand, such costs are higher than the deficit, causing what is called primary surplus, the deficit is consumed by the costs of debt servicing costs, i.e. by the interest paid to holders of treasury bonds. This undermines the State's ability to carry out its tasks.

The conclusion therefrom is that "the only thing" needed is for the interest of the treasury bonds to be lower than the current rate of the economy's rate of growth. Or, put different way, it is desirable to have such a rate of economic growth at which it is higher than the level of interest on the treasury bonds; or, expressing the same yet another way, the point is to make buyers of the treasury bonds accept their interest at a level lower than the rate of economic growth. That "only thing needed", however, entails a vast load of problems concerning the economic policy. The tools we have to alleviate that load of problems include a low rate of inflation and, even more importantly, negative inflation (deflation) as well as low interest rates.

\section{Debt as Property}

One of manifestations of ill understanding of the importance of deficit is seen in opinions that "we take debt at the cost of our grandchildren". Statements like that are wrong in that they fail to see the difference between an individual debt and the State debt. If a certain Smith takes a credit for 40 years to build a house, it is quite likely that his grandchildren will have to repay it. Also, his debt feeds the bank balances - it enriches bankers on the one hand, but on the other hand it provides "financial fuel" for paying the interest to depositors. In the case of State, however, 
this looks quite differently: what is debt for the State is property of its creditors. If the creditors are citizens of the State, either individually or institutionally (where bonds are bought by banks or pension funds), there is little sense in arguing that the State takes debt at their cost: after all "the money remains within the family". In fact, it is like to borrow money from members of one's own family. The family never suffers from that; nothing here happens at its cost - the only thing that occurs is that some rights to acquire goods and services are transferred among members of the family. The obligation of some members, related with that transfer, becomes property of other members: those who lent the money. Or, perhaps, instead of "becoming the property", it is only the form of owning the property that changes: from cash or bank deposit into securities, and in the case of our example of family loan - that of oral or written obligation to repay or a bill of exchange. In the case of a credit given to the State, money change its form into treasury bonds.

Therefore, the State does not really "take debt at the cost of future generations". Instead, it simply offers its citizens a form of saving alternative to common bank deposit, enabling them to take advantage of a particular type of investment in an instrument which is very secure. If I have invested in treasury bonds with a long term of maturity, my grandchildren are going to inherit the same and when the State buys the bonds out, my descendants will regain the money. Furthermore, they will also get the interest paid - after all, the interest is paid to domestic creditors thus improving their balances and, in the case of individual buyers, strengthens their purchasing power, intensifies demand and favors business. My money has fed the budget of my State, thanks to which infrastructure is built, education is funded as is health care, public safety and so on. In other words, all this favored better implementation of the tasks of the State, with - as already pointed out - relatively lower taxes and eventually all this occurs to great advantage of my children and grandchildren. So how can anybody complain about that "happening at my grandson's cost?" A nonsense, isn't it?

The interest is reverted to the economy as income of the bond holders - if, for example, it is pension funds that hold the bonds, the funds in question build pension capital, and where individuals hold the bonds, respective funds reinforce the budgets of their households. Is there any sense to point out that this occurs "at the cost of future generations"? The answer is there is not - such views stem from ignorance or misunderstanding of economics. Of course, the State not only has to pay the interest, it has to buy out the bonds at their maturity. Here a simple principle which is in common use, that of debt rollover, is enough to retain the relation of debt to GDP under control. The only important condition that stems from the specificity of the process is that the rate of economic growth should be significantly higher than the rate of deficit. This results from the mathematic nature of the relation of debt to the GDP, which is not known broadly enough and therefore needs to be reminded time and time again until it is finally rooted in social awareness. The relation is as follows:

$$
\frac{F}{G D P} \rightarrow \frac{\alpha}{g},
$$

where $F$ - public debt; $G D P$ - gross domestic product; $\alpha$ - the rate of deficit; $g$ - the rate of GDP growth.

The servicing and generation of debt as an effect of deficit, repeating in proportion $\alpha$, have their roots in the economy which generates the gross domestic product growing up at a rate g. In consequence, the relation of debt to the GDP gravitates toward the quotient of the rate of deficit by the rate of growth. Accordingly, the statement, stubbornly repeated and ill-informing the public opinion, that if the deficit is maintained permanently, the debt will rise up to infinity, is completely untrue. Instead, the debt is stabilized in proportion of the GDP defined by the mutual relation of the two rates.

Then, as explained before, it is essential that the interest rate on the treasury bonds is lower than the rate of growth: this is the condition under which the costs of debt servicing are not consuming the entire budget deficit. In this respect, the rate of growth is most important - and it is here that the crucial problem is. There is a view - rather popular unfortunately, but very illusive - that if we reduce the deficit by cutting the expenditure down, we shall 
get a higher rate of growth. Actually, we shall not, or at least this happens seldom, because as long as the economy operates with incomplete use made of its generating capacities and labor - which is usually the case - its growth requires money to be spent. Refusing to spend money hardly favors development. Any society that runs healthy economy is meant to generate goods and services, earn money doing that and spend that money by buying what was generated in the first place. Additionally, some of what was generated may be exported, which leads to acquiring foreign currencies, enabling the society to meet its demand with imported goods. This is, roughly, how the vast machinery of economy works and at the basis for its operation there are outlays. Especially during a crisis. To quote J.K. Galbraith from his most recent book, the best remedy to crisis is to foster the demand and respond with a healthy lot of expenses (Galbraith, 2006).

The State, however, also takes debt abroad. This way, on the one hand it acquires foreign assets which enable it to finance some budgetary outlays and feed the domestic financial system. The outlays lead to an increase in foreign currency reserves or they fund import, as an effect of which a trade deficit arises $(Z-X)>0$. On the other hand, the interest and funds sourced from the State buying out the bonds flow out abroad, thus decreasing the national income at hand domestically. This deepens the difference between the domestic product and the national product, to the disadvantage of the latter one. Borrowing money abroad may be a source of troubles, because while in the short term this practice increases the State's ability to implement its tasks, in the long run it may prove detrimental, especially when the domestic currency grows weaker, as an effect of which the costs of servicing foreign debt may become exorbitant.

\section{Surplus - A Risky Alternative to Deficit}

Critics of deficit seen as an economic evil avoid answering the question about the contrary situation: is, then, a surplus any good? A surplus in the economy means that the State has collected from its citizens, in the form of taxes, more than it gives back to them in the form of expenditure. From citizens' point of view, we are facing a sort of a nonsense - now this is sheer evil: the State takes money from individual entities (people and businesses) and refuses to give it back. Here again the difference becomes evident between what seems reasonable in the case of an individual person and in the case of the State understood as a collection of public institutions. For a household, to gather a surplus means that it grows wealthier, keeps savings, increases its property. Where, however, it is the State that achieves a surplus, this means the society's wasted money: the State collected it in the form of taxes and other tributes and the means taken away are not returned - the economy never saw the money back. Is this any kind of a "good" alternative for the "bad" deficit?

Then again, the issue is more complex than that. To have it clarified, one has to refer to the formula of the equilibrium of macroeconomic balances. If, therefore, we leave (S - I) at one side of the (1) equation, while moving $(Z-X)$ onto the other side, then we get $(\mathrm{X}-\mathrm{Z})$ with the "+" sign:

$$
(\mathrm{S}-\mathrm{I})=(\mathrm{G}-\mathrm{T})+(\mathrm{X}-\mathrm{Z})
$$

- and, in effect, we might say that the surplus of savings not transformed into the investments, put aside in a given year by households and businesses, defined by $(\mathrm{S}-\mathrm{I})$, may be consumed not only by the budgetary deficit $(\mathrm{G}-\mathrm{T})$, but also by a positive balance of foreign trade $(\mathrm{X}-\mathrm{Z})$, accompanied by (as results from the nature of payment balances) a surplus of our investments made abroad over foreign investments made in our country.

If, however, we assume equaling investment with savings, in a (rare) situation where the propensity to save happens to exactly match the propensity to invest (or the other way around), the equation:

$$
(Z-X)=(G-T)
$$

indicates that the potential state of budgetary surplus, when $(\mathrm{G}-\mathrm{T})<0$, results from a negative value of the second balance in the formula in which it is presented here, i.e. $(Z-X)<0$, which means a surplus in foreign exchange. Hence, although - as argued above - the state of a surplus is a sort of paradox, or at least something hardly desirable from the society's point 
of view, it still seems to be an unavoidable consequence of a situation where a surplus is built in foreign exchange of goods and services.

\section{Trade Balance or Current Account?}

So far, the $(\mathrm{Z}-\mathrm{X})$ or $(\mathrm{X}-\mathrm{Z})$ balance present in our equation was interpreted as an effect of foreign trade exchange - in the first version simply as trade deficit, in the second as the foreign exchange result, where expenses on import are subtracted from the income on export - i.e. the way it is presented in many textbooks.

The macroeconomic function of that balance results from the fact it is an element of a broader system known as the balance of payments. While the trade balance may be out of equilibrium, the payment balance has to be equable. It also takes into account changes occurring in balances - both in assets and in liabilities - as of the end of a year, i.e. being the effect of what happened, in the context of capital transfers over the year, in the property condition of various financial institutions, undertakings and the State. By saying equable we mean that the payment balance has to have zero in the bottom line. Therefore, any trade deficit has to be matched by a positive value of changes occurring in capital balances, i.e. if we import more than we export, an additional inflow of foreign currencies has to take place to finance such extra import.

Greater import, then, could take place thanks to an inflow of foreign currencies, for example in the form of investments in our domestic treasury bonds. This way the budgetary deficit is financed by foreign countries and the inflow of foreign currencies enables us to increase import, as an effect of which additional income, generated as a result of that deficit, is matched in the market by a supply of goods imported from abroad.

The payment balance in the basic, classic version takes the following form:

$$
(\mathrm{X}-\mathrm{Z})+\left(\mathrm{S}_{\mathrm{Z}}-\mathrm{I}_{\mathrm{Z}}\right)=0
$$

where $S_{z}$ are foreign investments attracted, i.e. means sourced from the pool of savings made abroad and invested in our country, providing us with an inflow of foreign cur- rencies; $I_{z}$ - our investments made abroad, credit given to foreign entities, i.e. investing our savings in foreign markets - which of course implies an outflow of foreign currencies from the country.

Therefore, a positive value of the $(\mathrm{X}-\mathrm{Z})$ balance has to be accompanied by negative capital balance, i.e. $\mathrm{I}_{\mathrm{z}}>\mathrm{S}_{\mathrm{z}}$. While this means a net outflow of foreign monies, this outflow makes our foreign investments or deposits which are going to yield income to their investors. One such particular "outflow" is to feed the official reserve assets of the central bank, but even in that case the funds are invested somewhere, for example in American treasury bonds or other stable and fairly liquid assets.

Economically, these two sides of the current account are of fundamentally different nature. $(\mathrm{X}-\mathrm{Z})$ is a flow of streams which occurs as a result of a flow of goods and services - much in the same way as the remaining elements of the equation (1) and (2) also have stream nature. $\left(S_{z}-I_{z}\right)$, on the other hand, while also being an effect of a flow (of currencies), is a balance record which reflects changes in assets and liabilities, i.e. in the volumes concerning resources.

However, it needs to be remembered that inflows of foreign capital represented here as $\mathrm{S}_{\mathrm{z}}$ are not our property; instead, they are our liability, appearing in records as liabilities of financial institutions. They are debt rather than our property; they are something foreign entities invested in our country to earn money from it and then take it back - a practice known as "withdrawal of capital". As a result of that inflow, we are not growing wealthier, although we might feel better off. If we do, then this is at somebody else's cost, and not free of charge...

In practice, it occurs that what is crucial for actual economic processes is that the trade balance expressed with a $(\mathrm{X}-\mathrm{Z})$ formula is not the only stream element of the payment balance; in fact it makes a part of a broader category of the current account balance. Apart from balances of exchange of goods and services, the current account includes balances of primary and secondary income. Primary income consists of the employees' wages, income on direct investments (profits) and on portfolio investments (dividends), income on interest and so on. Secondary income, on 
the other hand, includes transfers, such as donations, aid obtained from abroad, inheritances, alimonies, fines, indemnifications, lottery prizes, pension contributions, pensions and disability benefits, and even contributions paid to the European Union.

These additional elements have substantial influence upon the condition of the current account balance, i.e. upon the effect of flow of income and expenses streams between the country and foreign countries. In 2016, the balance of Poland's trade exchange with foreign countries amounted to the sum of PLN 12.8 bn - as the result of export at PLN 774.2 bn and import at PLN 761.3 bn.

The balance of services amounted to PLN 61.4 bn as the result of revenues (export of services) at PLN 196.4 bn and expenditure (import) at PLN 135.0 bn. In total, this gives PLN 74.2 on the plus side excellent outcome, capable of significantly strengthening Polish economy.

At the same time, however, substantial negative balances appeared in the income flows: PLN -73.5 bn in primary income, as an effect of expenditures (outflows) at PLN -123.4 bn and revenues (inflows) at PLN 49.8 bn; as well in secondary income, at PLN -6.1 bn as an effect of expenditure amounting to PLN -30.1 and revenues to PLN 24.0 bn. These negative income balances - for a total of PLN -79.6 billion, more than overweighed the positive effect of trade balance, eventually resulting in a negative current account.

Income inflows and outflows account, respectively, for only 4 and 8.3 percent of the GDP, but the negative outcome of that category, although much smaller in terms of volume, still overbalanced the positive outcome of import/export of goods and services - figures which accounted for 52 and 48 percent of the GDP, respectively.

It is quite clear, therefore, that to assess our macroeconomic balances expressed with equations (1) or (2), the entire current account as a whole has to be considered, rather than just the effects of trade exchange. It seems noteworthy, however, that the income part of the current account has a different influence upon macroeconomic processes than that relating to trade. As foreign currencies are flowing out of the country as an effect of import, such an outflow of income is accompanied by a reverse stream of the inflow of goods and services which serve to satisfy some needs, i.e. they compensate the outflow from the country of goods and services we are exporting. The income earned domestically meets the matching supply of goods and services from abroad, thus supplementing the country's own productive capacities (as mentioned above, import accounts for almost $50 \%$ of the GDP). When, on the other hand, the income flows out as a result of the income transfer in the second part of the current account balance (as we witnessed, in 2016 it was PLN -123.4 bn), this is only a reduction of domestic demand, a decrease of the purchasing power. What flows out is foreign currencies, so the transfers - for example of incomes earned in our country by foreigners - mean that the monies earned (the rights to acquire goods and services obtained in exchange for labor performed in the country) are exchanged for U.S. dollars or euros. In effect, some additional demand is generated for these currencies, which favors their strengthening and thereby contributes to the weakening of the Polish zloty.

This is how we approach another very important issue. Namely, the volume of this balance and its influence on the equilibrium of macroeconomic balances is determined by some very significant thing: the currencies' exchange rate. The exchange rate is crucial for the value of any category resulting from currency flows, i.e. mostly for the current account and its elements as well as public debt in its part which includes liabilities toward foreign countries.

The problem here is that there are two different sides to the exchange rate of foreign currencies. The first refers to markets: the rate results from the play of demand, supply and speculative activities on a given currency market. The other concerns the rate of the purchasing power parity which results from confrontations among the real values of goods and services. It is the rate of the purchasing power parity ${ }^{16}$ that determines the actual living standard compared with other countries, the real value of goods and services generated and the way we perceive our situation compared to other countries. As it turns out, according to the most recent data (July 2017), the exchange rate disparity, i.e. the difference between the market-based exchange rate and the purchasing power parity in relation to the U.S. dollar, is $-49 \%$ thus meaning 
that in terms of the market-based exchange rate, the Polish zloty is only half as strong, because the exchange rate reflecting the purchasing power parity is just half that high and instead of 3.71, it would be 1.91. In relation to the euro, the disparity amounts to $-39 \%$, i.e. instead of 4.24 , it would be 2.58 . In fact, most countries face negative disparity, which means that their currencies are actually weaker than this might seem from a simple comparison of prices. The phenomenon of currencies overvaluation, i.e. them being stronger than it would result from price relationships, only occurs in the case of three countries: Switzerland (27\%), Norway (12\%) and Sweden (10\%). Notably, according to this approach, the euro is also an undervalued currency, with the disparity of $-16 \%$, but this undervaluation is still much lower than that of the Polish currency.

The fundamental reason for the exchange rate disparity phenomenon is that there are other factors influencing a currency's exchange rate. One of them is the transfer of income. Foreigners working in a given country, including owners of foreign companies earning on the domestic market, generate demand for foreign currencies as they transfer their income abroad. This way, they strengthen their value, which leads to disparity between the market-based exchange rate and the purchasing power parity.

The importance of undervaluation of the market-based exchange rate in relation to the ppp-based one not only results from the fact that the value of the balance and the elements of the current account calculated at the market-based rate (both export and import, then) is higher almost by half, but also from another fact: that such a relation simply results from the Polish zloty being weak. If the exchange rate was stronger, for example at the disparity of $-16 \%$ as is the case with the euro, we would never have achieved export at the present level, because many exporters would have fallen off the export markets. Then, import would be higher as well, because imported products would be cheaper. In effect, costs borne for import would be reduced, thus increasing profits, but at the same time reserves would appear, making it possible to increase other costs. ${ }^{17}$ On the other hand, the current account deficit would also have to be substantially higher as well, which, as an effect of the impact of macroeconomic balances, would generate pressure increasing the budgetary deficit.

\section{Conclusions From International Comparisons}

Each macroeconomic volume which determines the elements of our equation is shaped as a cumulative effect of various complex processes, themselves influenced by a variety of factors, including the interest rate, the exchange rate, the rates and structure of taxation, general business outlooks domestically and abroad, as well as operation of institutions whose activities are related with those balances and their current condition. Therefore, budgetary deficit is a secondary effect of a great number of ever-changing and interrelated factors.

In order to examine practical processes according to which that mechanism works, we have gathered together sets of statistical data for a group of selected countries. These are mainly OECD member states (except for Mexico and Turkey), with Russia and China added. To collect the data it was necessary to consult a number of sources, as even some renowned international institutions sometimes gather their statistical data with rather poor reliability. The data were presented here according to rules adopted in the statistics published, so the budgetary balance, rather than being presented as in the formula (1), takes the form of $(T-G)$, i.e. the outcome of expenses being subtracted from budgetary revenues, so that the deficit has a negative value and the surplus has a positive value.

What these data demonstrate is, most of all, that budgetary deficit visibly prevails among these countries, while there are still several cases of budgetary surplus too. Interestingly, in the group of 35 countries in question, the state of perfect balance never occurred over the period of 16 years. A state close to zero, i.e. of a deficit lower than $0.1 \%$, occurred just four times out of the total of 560 cases $(16 \times 35)$, while that of deficits lower than $1 \%$ accounted for $10 \%$. In total, states of deficit accounted for $70 \%$, those of surplus for $30 \%$; the average deficit oscillated at $3.97 \%$ and the average surplus at $3.21 \%$. The way the deficit and surplus changed over time is presented in Table 2. 


\begin{tabular}{|c|c|c|c|c|c|c|c|c|c|c|c|c|c|c|c|c|}
\hline Country & 2000 & 2001 & 2002 & 2003 & 2004 & 2005 & 2006 & 2007 & 2008 & 2009 & 2010 & 2011 & 2012 & 2013 & 2014 & 2015 \\
\hline Norway & 15.1 & 13.2 & 9.05 & 7.25 & 10.9 & 14.8 & 18.0 & 17.1 & 18.7 & 10.3 & 11.0 & 13.5 & 13.9 & 10.8 & 8.77 & 6.44 \\
\hline Luxembourg & 5.94 & 5.97 & 2.47 & 0.19 & -1.3 & 0.08 & 1.96 & 4.2 & 3.36 & -0.69 & -0.67 & 0.52 & 0.35 & 0.96 & 1.47 & 1.53 \\
\hline South Korea & 4.36 & 2.97 & 3.51 & -1.96 & 0.23 & 1.55 & 2.33 & 4.24 & 2.34 & -1.32 & 0.97 & 0.98 & 1.01 & 1.34 & 1.27 & 1.41 \\
\hline Switzerland & -0.45 & -0.82 & -2.67 & -2.42 & -2.21 & -1.18 & 0.31 & 0.93 & 2.05 & 0.76 & 0.34 & 0.76 & 0.25 & -0.5 & -0.3 & 1.07 \\
\hline New Zealand & 1.67 & 1.35 & 3.31 & 3.43 & 3.89 & 4.54 & 5.08 & 4.29 & 0.50 & -2.78 & -7.04 & -4.01 & -2.12 & -0.73 & -0.12 & 0.70 \\
\hline Germany & 0.86 & -3.11 & -3.94 & -4.18 & -3.74 & -3.42 & -1.72 & 0.19 & -0.18 & -3.23 & -4.22 & -0.96 & -0.03 & -0.19 & 0.29 & 0.69 \\
\hline Sweden & 3.22 & 1.42 & -1.48 & -1.34 & 0.29 & 1.78 & 2.16 & 3.31 & 1.95 & -0.73 & -0.07 & -0.19 & -0.98 & -1.39 & -1.59 & 0.18 \\
\hline Estonia & -0.07 & 0.2 & 0.42 & 1.8 & 2.39 & 1.12 & 2.91 & 2.72 & -2.67 & -2.18 & 0.19 & 1.16 & -0.26 & -0.17 & 0.68 & 0.13 \\
\hline Czech Rep. & -3.47 & -5.34 & -6.27 & -6.4 & -2.71 & -3.11 & -2.25 & -0.69 & -2.11 & -5.51 & -4.41 & -2.72 & -3.93 & -1.25 & -1.93 & -0.63 \\
\hline Iceland & 1.23 & -0.98 & -2.81 & -3.13 & -0.33 & 4.46 & 5.87 & 4.92 & -13.1 & -9.7 & -9.77 & -5.59 & -3.74 & -1.85 & -0.06 & -0.84 \\
\hline Finland & 6.86 & 4.98 & 4.07 & 2.44 & 2.21 & 2.59 & 3.93 & 5.13 & 4.18 & -2.53 & -2.61 & -1.00 & -2.2 & -2.5 & -2.2 & -0.9 \\
\hline Austria & -2.07 & -0.66 & -1.42 & -1.83 & -4.86 & -2.55 & -2.58 & -1.39 & -1.53 & -5.39 & -4.47 & -2.59 & -2.22 & -1.37 & -2.74 & -1.04 \\
\hline China & -7.9 & -6.91 & -4.81 & -4.15 & -0.94 & -0.5 & 0.82 & 2.94 & 1.25 & 0.11 & 1.45 & 1.47 & 1.26 & 0.75 & -1.2 & -1.2 \\
\hline Latvia & -2.73 & -1.97 & -2.23 & -1.55 & -1.03 & -0.43 & -0.61 & -0.66 & -4.12 & -9.05 & -8.48 & -3.38 & -0.83 & -0.91 & -1.56 & -1.27 \\
\hline Canada & 2.65 & 0.53 & -0.23 & -0.13 & 0.77 & 1.56 & 1.83 & 1.82 & 0.18 & -3.89 & -4.75 & -3.32 & -2.53 & -1.88 & -0.5 & -1.32 \\
\hline Australia & -1.08 & -0.68 & 0.81 & 0.82 & 1.01 & 1.68 & 1.59 & 0.66 & -3.87 & -5.61 & -4.49 & -4.52 & -2.97 & -3.08 & -2.8 & -1.4 \\
\hline Hungary & -3.03 & -4.06 & -8.85 & -7.14 & -6.35 & -7.81 & -9.32 & -5.06 & -3.63 & -4.58 & -4.52 & -5.46 & -2.31 & -2.56 & -2.08 & -1.57 \\
\hline Denmark & 1.89 & 1.14 & -0.02 & -0.13 & 2.07 & 4.95 & 4.99 & 5.02 & 3.18 & -2.81 & -2.73 & -2.07 & -3.51 & -1.07 & 1.47 & -1.73 \\
\hline Ireland & 4.87 & 0.97 & -0.32 & 0.42 & 1.33 & 1.61 & 2.81 & 0.27 & -7.0 & -13.8 & -32.1 & -12.6 & -8.0 & -5.66 & -3.73 & -1.87 \\
\hline Netherlands & 1.88 & -0.35 & -2.08 & -3.02 & -1.72 & -0.26 & 0.21 & 0.21 & 0.22 & -5.43 & -4.99 & -4.29 & -3.88 & -2.37 & -2.27 & -1.89 \\
\hline Chile & -0.5 & -0.3 & -0.9 & 0.18 & 3.11 & 5.33 & 7.61 & 7.96 & 4.79 & -3.95 & -0.03 & 1.49 & 0.82 & -0.51 & -1.31 & -2.2 \\
\hline Belgium & -0.07 & 0.17 & 0.05 & -1.76 & -0.16 & -2.57 & 0.21 & 0.06 & -1.11 & -5.39 & -3.97 & -4.11 & -4.21 & -3.02 & -3.06 & -2.52 \\
\hline Poland & -2.97 & -4.78 & -4.85 & -6.08 & -5.04 & -3.96 & -3.56 & -1.85 & -3.6 & -7.25 & -7.34 & -4.82 & -3.69 & -4.05 & -3.43 & -2.56 \\
\hline Russia & 2.4 & 2.5 & 7.2 & 4.00 & 5.5 & 9.9 & 8.0 & 5.5 & 4.1 & -7.9 & -3.9 & 8.0 & -0.1 & -0.5 & -0.5 & -2.6 \\
\hline Italy & -1.32 & -3.39 & -3.07 & -3.41 & -3.57 & -4.17 & -3.59 & -1.53 & -2.69 & -5.27 & -4.25 & -3.71 & -2.93 & -2.69 & -2.99 & -2.61 \\
\hline Slovenia & -3.64 & -3.88 & -2.4 & -2.62 & -1.96 & -1.33 & -1.2 & -0.09 & -1.42 & -5.88 & -5.64 & -6.66 & -4.1 & -15.0 & -5.04 & -2.67 \\
\hline Slovakia & -12 & -6.4 & -8.09 & -2.7 & -2.31 & -2.88 & -3.59 & -1.95 & -2.43 & -7.8 & -7.48 & -4.28 & -4.34 & -2.72 & -2.71 & -2.71 \\
\hline France & -1.32 & -1.44 & -3.09 & -3.86 & -3.49 & -3.17 & -2.34 & -2.54 & -3.18 & -7.16 & -6.79 & -5.1 & -4.81 & -4.04 & -3.96 & -3.51 \\
\hline Israel & -3.43 & -5.63 & -7.08 & -7.35 & -5.16 & -4.18 & -1.93 & -0.93 & -2.94 & -5.91 & -4.07 & -3.41 & -4.97 & -4.2 & -3.48 & -3.6 \\
\hline United Kingdom & 1.11 & 0.39 & -1.95 & -3.22 & -3.43 & -3.32 & -2.74 & -2.91 & -4.88 & -10.2 & -9.56 & -7.62 & -8.27 & -5.66 & -5.73 & -4.33 \\
\hline Portugal & -3.21 & -4.79 & -3.34 & -4.42 & -6.19 & -6.19 & -4.33 & -3.01 & -3.77 & -9.81 & -11.2 & -7.38 & -5.66 & -4.84 & -7.15 & -4.36 \\
\hline USA & 0.8 & -1.37 & -4.73 & -5.88 & -5.44 & -4.15 & -2.97 & -3.55 & -7.02 & -12.7 & -12.0 & -10.6 & -8.86 & -5.33 & -4.91 & -4.6 \\
\hline Spain & -1.02 & -0.55 & -0.41 & -0.37 & -0.04 & 1.21 & 2.2 & 2.00 & -4.42 & -11.0 & -9.39 & -9.61 & -10.4 & -6.97 & -5.97 & -5.1 \\
\hline Japan & -7.51 & -6.04 & -7.71 & -7.67 & -5.95 & -4.81 & -1.28 & -2.09 & -1.86 & -8.84 & -8.3 & -8.81 & -8.66 & -7.68 & -6.18 & -6.7 \\
\hline Greece & -4.06 & -5.47 & -6.02 & -7.83 & -8.83 & -6.19 & -5.95 & -6.71 & -10.2 & -15.1 & -11.2 & -10.3 & -8.84 & -13.2 & -3.6 & -7.53 \\
\hline
\end{tabular}

Source: The Author's own, based on the OECD data. Countries ranked from the highest to the lowest score recorded in 2015. 
Table 2. The number of deficit and of surplus countries

\begin{tabular}{|l|l|l|l|l|l|l|l|l|}
\hline \multicolumn{1}{|c|}{ Specification } & $\mathbf{2 0 0 0}$ & $\mathbf{2 0 0 1}$ & $\mathbf{2 0 0 2}$ & $\mathbf{2 0 0 3}$ & $\mathbf{2 0 0 4}$ & $\mathbf{2 0 0 5}$ & $\mathbf{2 0 0 6}$ & $\mathbf{2 0 0 7}$ \\
\hline the number of deficit countries & 20 & 22 & 26 & 26 & 23 & 20 & 16 & 15 \\
\hline percentage of deficit countries (\%) & 57.1 & 62.9 & 74.3 & 74.3 & 65.7 & 57.1 & 45.7 & 42.9 \\
\hline the number of surplus countries & 15 & 13 & 9 & 9 & 12 & 15 & 19 & 20 \\
\hline percentage of surplus countries (\%) & 42.9 & 37.1 & 25.7 & 25.7 & 34.3 & 42.9 & 54.3 & 57.1 \\
\hline $\begin{array}{l}\text { how many times the number of deficit } \\
\text { countries is higher than the number of } \\
\text { surplus countries }\end{array}$ & 1.3 & 1.7 & 2.9 & 2.9 & 1.9 & 1.3 & 0.8 & 0.8 \\
\hline
\end{tabular}

\begin{tabular}{|l|l|l|l|l|l|l|l|l|}
\hline \multicolumn{1}{|c|}{ Specification } & $\mathbf{2 0 0 8}$ & $\mathbf{2 0 0 9}$ & $\mathbf{2 0 1 0}$ & $\mathbf{2 0 1 1}$ & $\mathbf{2 0 1 2}$ & $\mathbf{2 0 1 3}$ & $\mathbf{2 0 1 4}$ & $\mathbf{2 0 1 5}$ \\
\hline the number of deficit countries & 22 & 32 & 30 & 27 & 29 & 31 & 29 & 27 \\
\hline percentage of deficit countries (\%) & 62.9 & 91.4 & 85.7 & 77.1 & 82.9 & 88.6 & 82.9 & 77.1 \\
\hline the number of surplus countries & 13 & 3 & 5 & 8 & 6 & 4 & 6 & 8 \\
\hline percentage of surplus countries (\%) & 37.1 & 8.6 & 14.3 & 22.9 & 17.1 & 11.4 & 17.1 & 22.9 \\
\hline $\begin{array}{l}\text { how many times the number of deficit } \\
\text { countries is higher than the number of } \\
\text { surplus countries }\end{array}$ & 1.7 & 10.7 & 6.0 & 3.4 & 4.8 & 7.8 & 4.8 & 3.4 \\
\hline
\end{tabular}

Source: The Author's own.

As we see, the number of states of deficit increased considerably some time before the crisis, in the years 2002 and 2003, but in the years 2006 and 2007, i.e. directly precedent to the crisis, surplus countries prevailed. Then, in the years 2009-2015, deficits in the public finance had an evident advantage again. Generally, therefore, cases of budgetary surplus are in an obvious minority. One may say that the situation of budgetary surplus is a sort of peculiarity, considering that there were many more cases of deficit in most years over the period in question - usually over $70 \%$ and sometimes even over $80 \%$ and $90 \%$.

Still, there were also some particular situations. One example was Norway - over all the period under examination that country maintained a permanent budgetary surplus, reaching as high as over a dozen percent of GDP, for instance $18.7 \%$ in 2008. What is also rather peculiar is that Russia, Finland, New Zealand, as well as - sporadically - some other countries, were in a similar situation, at least until the crisis hit. Whether that resulted from their "extraor- dinary thrift" or from their governments acting like "prudent housewives" always striving to achieve a surplus, is a good question. Statistical data confirm that the ultimate budgetary outcome, whether it is deficit or surplus, is always related with the present condition of other macroeconomic interdependencies.

Next, let us consider the issue of the balance of current account. In Poland, the current account shows a negative result for a number of years, although it also happened over the recent years that the balance of trade exchange was positive $(2015,2016)$. While the balance in the services sector has remained positive on a regular basis for years, significant negative transfers of income still result in a negative outcome of the entire current account. In a similar way as in the case of the budget balance, the result of the current account is presented as under formula (2) - as $(X-Z)$, i.e. incomings minus expenditures.

These data make it clear that Norway's high budgetary surplus resulted from that country maintaining a huge trade sur- 
Table 3. Balances of current account $(X-Z)$ as \% of GDP in selected countries, 2000-2015

\begin{tabular}{|c|c|c|c|c|c|c|c|c|c|c|c|c|c|c|c|c|}
\hline Country & 2000 & 2001 & 2002 & 2003 & 2004 & 2005 & 2006 & 2007 & 2008 & 2009 & 2010 & 2011 & 2012 & 2013 & 2014 & 2015 \\
\hline Switzerland & 11.7 & 8.0 & 8.5 & 12.7 & 14.7 & 13.6 & 14.4 & 10.2 & 2.5 & 7.7 & 14.9 & 7.7 & 10.3 & 11.5 & 9.0 & 11.2 \\
\hline Ireland & 0.0 & 0.25 & 0.25 & 0.49 & -0.1 & -3.5 & -5.4 & -6.5 & -6.5 & -4.9 & -1.54 & -2.0 & -2.6 & 2.14 & 1.7 & 10.2 \\
\hline Netherlands & 1.8 & 2.3 & 2.4 & 5.2 & 6.8 & 6.1 & 7.9 & 6.0 & 4.2 & 5.8 & 7.4 & 9.1 & 10.8 & 9.9 & 8.9 & 8.7 \\
\hline Norway & 14.6 & 15.8 & 12.4 & 12.1 & 12.5 & 16.2 & 16.2 & 12.4 & 15.8 & 11.7 & 11.7 & 13.3 & 12.5 & 10.2 & 11.0 & 8.7 \\
\hline Germany & -1.7 & -0.4 & 1.9 & 1.4 & 4.5 & 4.6 & 5.7 & 6.8 & 5.6 & 5.8 & 5.6 & 6.1 & 7.0 & 6.8 & 7.3 & 8.4 \\
\hline South Korea & 1.9 & 0.5 & 0.8 & 1.7 & 3.9 & 1.4 & 0.4 & 1.1 & 0.3 & 3.7 & 2.6 & 1.6 & 4.2 & 6.2 & 6.0 & 7.7 \\
\hline Denmark & 1.4 & 2.9 & 1.9 & 3.2 & 2.4 & 4.2 & 2.9 & 1.4 & 2.8 & 3.4 & 5.7 & 5.8 & 5.8 & 7.2 & 6.2 & 7.1 \\
\hline Russia & 17.5 & 10.5 & 8.0 & 7.7 & 9.9 & 11 & 9.3 & 5.6 & 6.3 & 4.1 & 4.4 & 4.8 & 3.3 & 1.5 & 2.8 & 5.2 \\
\hline Slovenia & -2.7 & 0.1 & 1.0 & -0.7 & -2.6 & -1.9 & -1.8 & -4.2 & -5.3 & -0.6 & -0.1 & 0.2 & 2.6 & 4.8 & 6.2 & 5.2 \\
\hline Sweden & 4.5 & 6.2 & 4.7 & 5.9 & 6 & 6.1 & 8.2 & 8.2 & 7.9 & 6.0 & 6.0 & 5.6 & 5.6 & 5.3 & 4.6 & 5.2 \\
\hline Iceland & -9.0 & -4.8 & 0.7 & -3.9 & -9.3 & -14 & -20.7 & -16.3 & -23.7 & -5.2 & -2.3 & -4.1 & -6.4 & 6.1 & 3.9 & 5.1 \\
\hline Luxembourg & 11.9 & 7.9 & 9 & 6.7 & 12.1 & 11.1 & 10 & 9.9 & 7.9 & 7.0 & 6.8 & 6.1 & 5.9 & 5.5 & 5.1 & 5.1 \\
\hline Israel & -1.6 & -1.6 & -1.1 & 0.5 & 5.1 & 2.8 & 4.4 & 3.1 & 1.5 & 3.8 & 3.4 & 2.6 & 0.6 & 3.3 & 3.8 & 4.6 \\
\hline Hungary & -8.5 & -5.8 & -6.4 & -8.0 & -8.5 & -7 & -7.1 & -7.1 & -6.9 & -0.8 & 0.3 & 0.8 & 1.7 & 3.8 & 2.0 & 3.2 \\
\hline Japan & 2.7 & 2 & 2.6 & 3.1 & 3.8 & 3.6 & 3.9 & 4.7 & 2.8 & 2.8 & 3.9 & 2.1 & 1.0 & 0.9 & 0.7 & 3.1 \\
\hline China & 1.7 & 1.3 & 2.4 & 2.6 & 3.5 & 5.8 & 8.4 & 9.9 & 9.1 & 4.8 & 3.9 & 1.8 & 2.5 & 1.5 & 2.6 & 3.0 \\
\hline Estonia & -5.3 & -5.2 & -10.6 & -11.3 & -11.4 & -9.9 & -15.2 & -15.8 & -9.2 & 2.7 & 1.8 & 1.3 & -1.9 & -0.3 & 0.9 & 2.2 \\
\hline Austria & -0.7 & -0.8 & 2.1 & 1.6 & 2.1 & 2.3 & 3.3 & 3.8 & 4.5 & 2.6 & 2.9 & 1.6 & 1.5 & 2.0 & 2.4 & 1.9 \\
\hline Italy & -0.5 & -0.1 & -0.7 & -1.2 & -0.9 & -1.6 & -2.5 & -2.3 & -2.8 & -1.8 & -3.4 & -3.0 & -0.4 & 1.0 & 1.8 & 1.6 \\
\hline Spain & -4.4 & -4.4 & -3.7 & -3.9 & -5.6 & -7.5 & -9.0 & -9.7 & -9.3 & -4.3 & -3.9 & -3.2 & -0.3 & 1.5 & 1.0 & 1.4 \\
\hline Czech Rep. & -4.4 & -4.9 & -5.2 & -5.8 & -4.8 & -0.9 & -2.0 & -4.2 & -1.9 & -2.4 & -3.6 & -2.2 & -1.5 & -0.5 & 0.2 & 0.9 \\
\hline Belgium & 4.0 & 3.5 & 4.5 & 3.52 & 3.27 & 2.09 & 1.9 & 1.97 & -1.0 & -1.09 & 1.75 & -1.07 & -0.05 & -0.33 & -0.67 & 0.4 \\
\hline Portugal & -10.9 & -10.4 & -8.5 & -7.2 & -8.4 & -9.9 & -10.7 & -9.8 & -12.2 & -10.4 & -10.2 & -6.0 & -1.8 & 1.6 & 0.0 & 0.4 \\
\hline Slovakia & -2.4 & -5.7 & -5.6 & -0.6 & -7.6 & -8.2 & -7.7 & -5.4 & -6.3 & -3.4 & -4.7 & -5.0 & 1.0 & 1.8 & 1.2 & 0.2 \\
\hline Greece & -7.5 & -6.9 & -6.2 & -6.3 & -5.6 & -7.4 & -10.8 & -14 & -14.5 & -10.9 & -10.1 & -9.9 & -2.5 & -2.1 & -1.6 & 0.1 \\
\hline France & 1.2 & 1.5 & 1.2 & 0.9 & 0.4 & 0.0 & 0.0 & -0.3 & -1.0 & -0.8 & -0.8 & -1.0 & -1.2 & -0.9 & -1.1 & -0.2 \\
\hline Finland & 8.4 & 9.3 & 8.7 & 5.0 & 6.4 & 3.8 & 3.8 & 3.9 & 2.2 & 2.0 & 1.3 & -1.8 & -2.0 & -1.6 & -1.2 & -0.4 \\
\hline Poland & -6.0 & -3.1 & -2.8 & -2.5 & -5.4 & -2.6 & -4.0 & -6.4 & -6.7 & -4.1 & -5.4 & -5.2 & -3.7 & -1.3 & -2.1 & -0.6 \\
\hline Latvia & -3.7 & -6.0 & -5.5 & -7.2 & -11.7 & -11.7 & -21.1 & -20.8 & -12.6 & 7.9 & 2.1 & -3.2 & -3.6 & -2.7 & -2.0 & -0.8 \\
\hline Chile & -1.1 & -1.5 & -0.8 & -1.0 & 2.1 & 1.2 & 4.6 & 4.3 & -1.8 & 2.0 & 1.6 & -1.2 & -3.6 & -3.7 & -1.3 & -2.0 \\
\hline USA & -4.0 & -3.7 & -4.2 & -4.5 & -5.2 & -5.7 & -5.8 & -5.0 & -4.7 & -2.7 & -3.0 & -3.0 & -2.8 & -2.2 & -2.3 & -2.6 \\
\hline Canada & 2.5 & 2.1 & 1.7 & 1.2 & 2.3 & 1.9 & 1.4 & 0.8 & 0.2 & -3.0 & -3.6 & -2.8 & -3.6 & -3.2 & -2.3 & -3.2 \\
\hline New Zealand & -3.3 & -0.8 & -2.1 & -2.4 & -4.5 & -7.0 & -7.1 & -6.8 & -7.7 & -2.5 & -2.3 & -2.9 & -3.9 & -3.1 & -3.2 & -3.2 \\
\hline Australia & -3.9 & -2.1 & -3.7 & -5.4 & -6.2 & -5.9 & -5.8 & -6.7 & -4.9 & -4.6 & -3.6 & -3.0 & -4.1 & -3.2 & -2.9 & -4.7 \\
\hline $\begin{array}{l}\text { United } \\
\text { Kingdom }\end{array}$ & -2.1 & -1.9 & -2.0 & -1.7 & -1.8 & -1.2 & -2.2 & -2.5 & -3.5 & -2.9 & -2.8 & -1.8 & -3.7 & -4.4 & -4.7 & -5.4 \\
\hline
\end{tabular}

Source: The Author's own, based on: World Bank, OECD, Trading Economics. Countries ranked from the highest to the lowest score recorded in 2015. 
plus all the time, which resulted from the income made from selling natural gas. Therefore, its budgetary surplus has not emerged due to the society being subject to drastic taxation, out of proportion to the needs of the budget, or to a reduction of budgetary expenditure. Instead, this resulted from the fact that the State was taking over the income of companies which achieved exorbitant profits in foreign currencies from selling natural gas. That action was necessary because otherwise an outflow, onto the market, of foreign currencies making the country's trade surplus would have caused excessive strengthening of the Norwegian krone, which even without that is overvalued anyway. This, in turn, would have deteriorated the financial condition of other exporters. By gathering in the currencies earned from the sale of natural gas, the State prevents an excessive strengthening of its national currency. The Norwegian krone is thus weakened compared to what exchange rate it would have unless the government had got involved in this procedure. In effect, this also relatively increases the value of its registered budgetary surplus. That surplus constitutes frozen public savings, not directed onto the market - the money which, once freely flowing to the market, would put the economy out of balance. Therefore, this way the budgetary surplus stemming from a high trade surplus serves to stabilize the economy.

The figures given in the tables illustrate the state of a given balance in relation to the GDP. It seems pertinent to remind here that the value of both export and import, as well as - quite obviously - that of the current account, results from the way the exchange rate varies: relative weakness of the domestic currency increases the value of those figures, expressed in that currency, while any strengthening of the currency decreases that value. As a consequence of this phenomenon, the share of both import and export is relatively high, as is, of course, their share in the GDP. The table below presents the share of export in the GDP in individual countries.

As we see, both in Luxemburg and, over recent years, in Ireland too, the value of export exceeded that of the GDP, which was an obvious effect of those countries' transit profile. It also seems noteworthy that in Poland the relation of export to the
GDP in 2015, although in earlier years as well, was visibly higher than in Germany, and even if it was lower in certain years, it still remained at a similar level. At present it accounts for nearly $50 \%$ of the GDP. At the same time, however, the marketbased exchange rate was distinctly lower than the exchange rate resulting from the purchasing power parity. As stated above, a relative weakness of the domestic currency increases the relation of the elements of current account to the GDP and to the very balance, yet at the same time it favors export by decreasing both profitability and the volume of import, and therefore this works towards increasing the value of the $(\mathrm{X}-\mathrm{Z})$ difference. This means that a relative weakness of the domestic currency also decreases the $(Z-X)$, i.e. it diminishes the scale of foreign financing of budgetary deficit. However, what is very important, any weakening of domestic currency not only increases the costs of servicing of foreign debt, but at the same time it also increases the value of the foreign portion of debt. As a consequence of that, variations of the rate of exchange alone may result in the value of debt in relation to the GDP exceeding the magical threshold of $60 \%$, specified in the Treaty of Maastricht and imprudently provided for in the Polish Constitution.

Whereas, as mentioned above, countries having a budgetary deficit generally prevail, occurring in numbers clearly greater than that of the surplus countries, as far as financial effects of foreign exchange are concerned (i.e. the current account), both groups, i.e. countries with a deficit and those having a surplus on the current account, were more or less equal in numbers until 2012. Then, form 2013 onwards, countries having a surplus in their current account balance began to prevail by becoming more numerous. This means that countries with strong, export-oriented economies grow more powerful, as witnessed by their share in that group of countries increasing, respectively, to $60 \%, 63 \%$ and $71 \%$. Moreover, over the recent years they also enjoy an evident advantage in terms of their average value of the current account balances.

As demonstrated by empirical data, there is an obvious relationship between the state of budget and the state of the current account (table 5). 
Table 4. Relation of export to the GDP expressed as percentage for selected countries, 2000-2015

\begin{tabular}{|c|c|c|c|c|c|c|c|c|c|c|c|c|c|c|c|c|}
\hline Country & 2000 & 2001 & 2002 & 2003 & 2004 & 2005 & 2006 & 2007 & 2008 & 2009 & 2010 & 2011 & 2012 & 2013 & 2014 & 2015 \\
\hline Luxembourg & 147.5 & 148.7 & 142.2 & 139.6 & 152.7 & 161.1 & 175.6 & 184.2 & 189.0 & 166.5 & 175.1 & 177.9 & 186.1 & 191.8 & 208.7 & 235.6 \\
\hline Ireland & 94.5 & 95.3 & 90.5 & 80.9 & 80.5 & 79.6 & 79.0 & 80.7 & 84.2 & 93.5 & 103.4 & 102.4 & 106.8 & 106.1 & 113.8 & 124.0 \\
\hline Slovakia & 54.1 & 57.8 & 57.5 & 62.2 & 68.7 & 72.0 & 81.0 & 83.3 & 80.0 & 67.6 & 76.3 & 85.0 & 91.4 & 93.8 & 91.8 & 93.5 \\
\hline Hungary & 66.8 & 64.9 & 58.1 & 56.4 & 59.7 & 62.8 & 74.3 & 78.3 & 79.6 & 74.8 & 82.2 & 87.2 & 86.8 & 86.0 & 88.7 & 90.7 \\
\hline Czech Rep. & 48.3 & 49.1 & 45.2 & 47.1 & 57.4 & 62.3 & 65.3 & 66.6 & 63.4 & 58.8 & 66.2 & 71.3 & 76.2 & 76.9 & 82.5 & 83.0 \\
\hline Belgium & 71.9 & 71.0 & 70.3 & 68.6 & 70.4 & 73.5 & 75.7 & 77.5 & 79.7 & 69.3 & 76.4 & 81.6 & 82.3 & 81.8 & 83.2 & 82.9 \\
\hline Netherlands & 66.5 & 63.8 & 60.8 & 59.7 & 63.5 & 66.6 & 69.3 & 70.3 & 71.6 & 63.2 & 72.0 & 77.4 & 81.9 & 82.0 & 82.6 & 82.5 \\
\hline Estonia & 61.6 & 61.3 & 58.3 & 57.4 & 61.5 & 65.9 & 63.5 & 63.2 & 66.8 & 60.8 & 75.1 & 86.5 & 86.0 & 84.5 & 83.1 & 79.3 \\
\hline Slovenia & 50.0 & 51.7 & 52.2 & 50.9 & 55.0 & 59.6 & 64.7 & 67.6 & 66.1 & 57.2 & 64.3 & 70.4 & 73.3 & 75.2 & 76.4 & 77.9 \\
\hline Switzerland & 52.2 & 50.9 & 49.0 & 48.2 & 51.6 & 53.9 & 56.7 & 61.6 & 63.0 & 57.4 & 64.2 & 65.8 & 67.3 & 72.3 & 64.9 & 62.9 \\
\hline Latvia & 36.9 & 38.1 & 36.6 & 36.1 & 39.1 & 43.2 & 40.0 & 38.5 & 39.5 & 42.6 & 53.7 & 57.9 & 61.4 & 60.3 & 59.6 & 59.0 \\
\hline Denmark & 44.9 & 45.6 & 45.7 & 43.9 & 44.0 & 47.5 & 50.7 & 51.5 & 54.2 & 47.1 & 50.5 & 53.8 & 54.6 & 54.8 & 54.5 & 55.2 \\
\hline Iceland & 32.4 & 37.3 & 35.9 & 33.0 & 32.7 & 30.6 & 31.1 & 33.4 & 41.2 & 49.7 & 53.7 & 56.6 & 57.0 & 55.4 & 53.3 & 53.7 \\
\hline Austria & 43.4 & 44.7 & 45.3 & 44.6 & 46.9 & 48.6 & 50.8 & 52.5 & 53.2 & 44.9 & 51.0 & 53.7 & 53.8 & 53.2 & 53.0 & 53.1 \\
\hline Poland & 27.2 & 27.2 & 28.8 & 33.4 & 34.3 & 34.6 & 37.9 & 38.6 & 37.9 & 37.2 & 40.1 & 42.6 & 44.4 & 46.3 & 47.6 & 49.6 \\
\hline Germany & 30.8 & 31.9 & 32.6 & 32.6 & 35.4 & 37.7 & 41.2 & 43.0 & 43.5 & 37.8 & 42.3 & 44.8 & 46.0 & 45.5 & 45.7 & 46.8 \\
\hline South Korea & 35.0 & 32.7 & 30.8 & 32.7 & 38.3 & 36.8 & 37.2 & 39.2 & 50.0 & 47.5 & 49.4 & 55.7 & 56.3 & 53.9 & 50.3 & 45.9 \\
\hline Sweden & 44.1 & 43.8 & 42.1 & 41.2 & 43.4 & 45.9 & 48.2 & 48.3 & 49.8 & 44.5 & 46.2 & 46.7 & 46.3 & 43.8 & 45.0 & 45.6 \\
\hline Portugal & 28.2 & 27.4 & 26.9 & 26.8 & 27.3 & 26.7 & 29.9 & 31.0 & 31.1 & 27.1 & 29.9 & 34.3 & 37.7 & 39.5 & 40.1 & 40.6 \\
\hline Norway & 45.7 & 45.0 & 40.4 & 39.6 & 41.1 & 43.4 & 44.7 & 43.3 & 45.9 & 39.2 & 39.8 & 41.3 & 40.6 & 39.2 & 38.9 & 37.4 \\
\hline Finland & 42.1 & 39.7 & 39.1 & 37.3 & 38.6 & 40.3 & 43.2 & 44.0 & 45.1 & 36.3 & 38.7 & 39.2 & 39.5 & 38.8 & 37.2 & 36.8 \\
\hline Spain & 28.6 & 27.9 & 26.5 & 25.4 & 25.2 & 24.7 & 24.9 & 25.7 & 25.3 & 22.7 & 25.5 & 28.9 & 30.7 & 32.2 & 32.7 & 33.2 \\
\hline Greece & 23.7 & 22.8 & 20.1 & 18.5 & 20.7 & 21.3 & 21.2 & 22.5 & 23.4 & 19.0 & 22.1 & 25.5 & 28.7 & 30.4 & 32.5 & 31.9 \\
\hline Canada & 44.2 & 42.0 & 40.0 & 36.8 & 37.3 & 36.8 & 35.3 & 34.2 & 34.3 & 28.4 & 29.1 & 30.6 & 30.2 & 30.2 & 31.6 & 31.6 \\
\hline Israel & 35.6 & 31.3 & 32.9 & 34.7 & 39.2 & 40.8 & 40.7 & 40.4 & 38.5 & 33.3 & 35.1 & 36.1 & 36.1 & 33.4 & 32.2 & 30.7 \\
\hline Italy & 25.7 & 25.7 & 24.5 & 23.4 & 24.1 & 24.7 & 26.2 & 27.4 & 27.0 & 22.5 & 25.2 & 27.0 & 28.6 & 28.9 & 29.3 & 30.1 \\
\hline France & 28.2 & 27.8 & 27.0 & 25.6 & 25.9 & 26.4 & 27.2 & 27.1 & 27.4 & 24.1 & 26.0 & 27.8 & 28.5 & 28.6 & 28.9 & 30.0 \\
\hline Chile & 29.3 & 30.9 & 31.5 & 33.9 & 37.9 & 38.4 & 42.4 & 43.8 & 41.5 & 37.2 & 38.1 & 38.1 & 34.3 & 32.3 & 33.4 & 30.0 \\
\hline Russia & 44.1 & 36.9 & 35.2 & 35.2 & 34.4 & 35.2 & 33.7 & 30.2 & 31.3 & 27.9 & 29.2 & 28.3 & 27.4 & 26.6 & 27.5 & 29.5 \\
\hline United Kingdom & 25.0 & 24.8 & 23.9 & 23.6 & 23.5 & 24.7 & 26.8 & 24.9 & 26.9 & 26.2 & 28.3 & 30.5 & 29.8 & 29.8 & 28.1 & 27.6 \\
\hline China & 21.2 & 20.8 & 23.0 & 27.8 & 31.8 & 34.5 & 37.2 & 35.9 & 32.0 & 24.4 & 26.3 & 26.5 & 25.4 & 24.5 & 24.1 & 22.0 \\
\hline New Zealand & 35.7 & 35.4 & 32.8 & 29.8 & 29.5 & 28.3 & 29.6 & 29.2 & 32.0 & 28.7 & 30.3 & 30.4 & 28.8 & 28.8 & 28.0 & 20.7 \\
\hline Australia & 19.4 & 22.1 & 20.7 & 18.9 & 17.0 & 18.1 & 19.6 & 19.9 & 19.8 & 22.5 & 19.4 & 21.1 & 21.3 & 19.8 & 20.9 & 19.8 \\
\hline Japan & 10.6 & 10.2 & 11.0 & 11.6 & 13.0 & 14.0 & 15.9 & 17.5 & 17.4 & 12.5 & 15.0 & 14.9 & 14.5 & 15.9 & 17.5 & 17.6 \\
\hline USA & 10.7 & 9.7 & 9.1 & 9.0 & 9.6 & 10.0 & 10.7 & 11.5 & 12.5 & 11.0 & 12.4 & 13.6 & 13.6 & 13.6 & 13.7 & 12.6 \\
\hline
\end{tabular}

Source: The Author's own, based on: World Bank, countries ranked from the highest to the lowest score in 2015 
Table 5. Compatibility of current account balances and budget in a group of 35 countries

\begin{tabular}{|l|l|l|l|l|l|l|l|l|}
\hline \multicolumn{1}{|c|}{ Specification } & $\mathbf{2 0 0 0}$ & $\mathbf{2 0 0 1}$ & $\mathbf{2 0 0 2}$ & $\mathbf{2 0 0 3}$ & $\mathbf{2 0 0 4}$ & $\mathbf{2 0 0 5}$ & $\mathbf{2 0 0 6}$ & $\mathbf{2 0 0 7}$ \\
\hline $\begin{array}{l}\text { The number of countries having } \\
\text { compatible balances }\end{array}$ & 24 & 26 & 19 & 18 & 21 & 20 & 24 & 26 \\
\hline $\begin{array}{l}\text { Share of countries having compatible } \\
\text { balances in the total }\end{array}$ & 68.6 & 74.3 & 54.3 & 51.4 & 60.0 & 57.1 & 68.6 & 74.3 \\
\hline $\begin{array}{l}\text { in which: countries with deficit on } \\
\text { current account and with budgetary } \\
\text { deficit }\end{array}$ & 15 & 16 & 13 & 13 & 13 & 11 & 11 & 12 \\
\hline $\begin{array}{l}\text { Share of countries having compatible } \\
\text { balances within the group of countries } \\
\text { having deficit on current account }\end{array}$ & 75.0 & 84.2 & 81.3 & 76.5 & 76.5 & 64.7 & 64.7 & 66.7 \\
\hline $\begin{array}{l}\text { Share of countries having compatible } \\
\text { balances within the group of countries } \\
\text { having budgetary deficit }\end{array}$ & 75.0 & 72.7 & 50.0 & 50.0 & 56.5 & 55.0 & 68.8 & 80.0 \\
\hline $\begin{array}{l}\text { - countries with surplus on current } \\
\text { account and with budgetary surplus }\end{array}$ & 9 & 10 & 6 & 5 & 8 & 9 & 13 & 14 \\
\hline $\begin{array}{l}\text { Share of countries having compatible } \\
\text { balances within the group of countries } \\
\text { having surplus on current account }\end{array}$ & 64.3 & 62.5 & 31.6 & 27.8 & 44.4 & 52.9 & 76.5 & 82.4 \\
\hline $\begin{array}{l}\text { Share of countries having compatible } \\
\text { balances within the group of countries } \\
\text { having budgetary surplus }\end{array}$ & 60.0 & 76.9 & 66.7 & 55.6 & 66.7 & 60.0 & 68.4 & 70.0 \\
\hline
\end{tabular}

\begin{tabular}{|l|l|l|l|l|l|l|l|l|}
\hline \multicolumn{1}{|c|}{ Specification } & $\mathbf{2 0 0 8}$ & $\mathbf{2 0 0 9}$ & $\mathbf{2 0 1 0}$ & $\mathbf{2 0 1 1}$ & $\mathbf{2 0 1 2}$ & $\mathbf{2 0 1 3}$ & $\mathbf{2 0 1 4}$ & $\mathbf{2 0 1 5}$ \\
\hline $\begin{array}{l}\text { The number of countries having } \\
\text { compatible balances }\end{array}$ & 29 & 21 & 21 & 25 & 23 & 18 & 18 & 14 \\
\hline $\begin{array}{l}\text { Share of countries having compatible } \\
\text { balances in the total }\end{array}$ & 82.9 & 60.0 & 60.0 & 71.4 & 65.7 & 51.4 & 51.4 & 40.0 \\
\hline $\begin{array}{l}\text { in which: countries with deficit on } \\
\text { current account and with budgetary } \\
\text { deficit }\end{array}$ & 18 & 18 & 16 & 18 & 18 & 14 & 12 & 7 \\
\hline $\begin{array}{l}\text { Share of countries having compatible } \\
\text { balances within the group of countries } \\
\text { having deficit on current account }\end{array}$ & 90 & 100 & 100 & 94.74 & 94.74 & 100 & 100 & 70 \\
\hline $\begin{array}{l}\text { Share of countries having compatible } \\
\text { balances within the group of countries } \\
\text { having budgetary deficit }\end{array}$ & 81.8 & 56.3 & 53.3 & 66.7 & 62.1 & 45.2 & 41.4 & 25.9 \\
\hline $\begin{array}{l}\text { - countries with surplus on current } \\
\text { account and with budgetary surplus }\end{array}$ & 11 & 3 & 5 & 7 & 5 & 4 & 6 & 7 \\
\hline $\begin{array}{l}\text { Share of countries having compatible } \\
\text { balances within the group of countries } \\
\text { having surplus on current account }\end{array}$ & 73.3 & 17.7 & 26.3 & 43.8 & 31.3 & 19.1 & 27.3 & 28.0 \\
\hline $\begin{array}{l}\text { Share of countries having compatible } \\
\text { balances within the group of countries } \\
\text { having budgetary surplus }\end{array}$ & 84.6 & 100 & 100 & 87.5 & 83.3 & 100 & 100 & 87.5 \\
\hline
\end{tabular}

\section{Source: The Author's own.}


However, the very numbers of countries within the groups are enough here to see that this relation is not symmetrical, the state of the budget being the factor of crucial influence, which is especially evident following the crisis. From 2008 on almost all countries having a budgetary deficit faced a deficit on their current account at the same time, while those having a budgetary surplus also had some surplus on their current account (Norway, for example). However, looking the other way round, countries having a deficit on their current account not necessarily experienced a budgetary deficit in parallel and those having a surplus on their current account also had a budgetary surplus - although this sort of relationship is less obvious. As a result, the correlation of balances of budget and of current account was positive and strongest in the years 2008 and 2009 (correlation coefficient at 0.8 and 0.72 , respectively), but later on it wavered gradually down to 0.42 ; before the crisis it was rather mediocre, even at levels between 0.33 and 0.38 (in the years 2003 to 2006). Accordingly, it seems evident that these relationships require a more profound analysis, carried out using methods of statistics.

Tables 1 and 3 present two macroeconomic balances: the balance of the country $(\mathrm{T}-\mathrm{G})$ and the balance of stream relations with foreign countries, specified by the current account: $(\mathrm{X}-\mathrm{Z})$. In order to have a complete picture, it is necessary to know the status of the balance $(\mathrm{S}-\mathrm{I})$. However, to acquire reliable statistical data in this area is, unfortunately, rather difficult. Statistics of savings expressed as gross savings, or those of investments expressed as gross fixed capital formation, provided by either OECD or the World Bank data, do not give a $(\mathrm{S}-\mathrm{I})$ result which corresponds to the values of budget balances and $(Z-X)$. Put simply, the equality $(S-I)=(G-T)+(X-Z)$ fails to occur in this context. By the way, it is quite difficult to define macroeconomic values of savings and investments alike with any reasonable accuracy, due to specificities and ambiguities involved in those economic categories. This is why the state of balances $(\mathrm{S}-\mathrm{I})$ was calculated as a figure resulting from the state of budget and of current account - this finding is presented in Table 6.
As we see, there were many countries having a surplus of savings over investments. Over the recent years 2013-2015, as well as in some earlier years, Poland had a surplus of savings, too. Interestingly, this is contradictory to the results from the World Bank data: they suggest that Poland had a deficit of gross savings compared to investments (gross fixed capital formation) in all the years in the period under examination. The suggestions stemming from the World Bank data find no affirmation in the fact that the banking sector featured overliquidity which was absorbed by the central bank.

\section{Rates of Growth and Mutual Relations; Conclusions}

The values of individual balances may also be compared to their effect, i.e. to growth rate indicators, as presented in Table 7 below.

As we see, in 2009 almost all the countries included in this comparison suffered some recession. In some of them it was very serious, in some it was experienced over the subsequent years. However, apart from the crisis years, generally the countries in question enjoyed economic growth. The comparison of rates of growth in the surplus countries indicates that usually the rate of growth in those countries was higher - as illustrated in Table 8 .

While, as mentioned before, the number of deficit countries is clearly larger than that of the surplus countries (apart from the years 2006 and 2007, i.e. just before the crisis), the average rate of growth of deficit countries was still lower, both in general and in specific years, to decline drastically in 2008. Then, in 2009, the crisis entailed the global recession - a negative average rate of growth. It was only in 2015 that the rates of growth practically equaled in both deficit and surplus countries.

Macroeconomic balances, also known as twin balances, are the effect of formation and transfer of macroeconomic streams. Here it would be wrong to speak about causal relationships; actually what we have are bilateral and multi-lateral dependencies, or even more: the way particular balances are shaped results from a vast variety of factors determining their ingredients. Such factors include, for example, exchange rate, general business outlooks, condition of 
Table 6. The balance of savings and investments (S - I) as percentage of GDP (Gross Domestic Product), 2000-2015

\begin{tabular}{|c|c|c|c|c|c|c|c|c|c|c|c|c|c|c|c|c|}
\hline Country & 2000 & 2001 & 2002 & 2003 & 2004 & 2005 & 2006 & 2007 & 2008 & 2009 & 2010 & 2011 & 2012 & 2013 & 2014 & 2015 \\
\hline Ireland & -4.9 & -0.7 & 0.6 & 0.1 & -1.4 & -5.2 & -8.2 & -6.8 & 0.5 & 8.9 & 30.6 & 10.6 & 5.4 & 7.8 & 5.4 & 12.1 \\
\hline Netherlands & -0.1 & 2.7 & 4.5 & 8.2 & 8.5 & 6.4 & 7.7 & 5.8 & 4.0 & 11.2 & 12.4 & 13.4 & 14.7 & 12.3 & 11.2 & 10.6 \\
\hline Switzerland & 12.2 & 8.8 & 11.2 & 15.1 & 16.9 & 14.8 & 14.1 & 9.3 & 0.5 & 6.9 & 14.6 & 6.9 & 10.1 & 12.0 & 9.3 & 10.1 \\
\hline Japan & 10.2 & 8.0 & 10.3 & 10.8 & 9.8 & 8.4 & 5.2 & 6.8 & 4.7 & 11.6 & 12.2 & 10.9 & 9.7 & 8.6 & 6.9 & 9.8 \\
\hline Denmark & -0.5 & 1.8 & 1.9 & 3.3 & 0.3 & -0.8 & -2.1 & -3.6 & -0.4 & 6.2 & 8.4 & 7.9 & 9.3 & 8.3 & 4.7 & 8.8 \\
\hline Israel & 1.8 & 4.0 & 6.0 & 7.9 & 10.3 & 7.0 & 6.3 & 4.0 & 4.4 & 9.7 & 7.5 & 6.0 & 5.6 & 7.5 & 7.3 & 8.2 \\
\hline Slovenia & 0.9 & 4.0 & 3.4 & 1.9 & -0.6 & -0.6 & -0.6 & -4.1 & -3.9 & 5.3 & 5.5 & 6.9 & 6.7 & 19.8 & 11.2 & 7.9 \\
\hline Russia & 15.1 & 8.0 & 0.8 & 3.7 & 4.4 & 1.1 & 1.3 & 0.1 & 2.2 & 12.0 & 8.3 & -3.2 & 3.4 & 2.0 & 3.3 & 7.8 \\
\hline Germany & -2.6 & 2.7 & 5.8 & 5.6 & 8.2 & 8.0 & 7.4 & 6.6 & 5.8 & 9.0 & 9.8 & 7.1 & 7.0 & 7.0 & 7.0 & 7.7 \\
\hline Greece & -3.4 & -1.4 & -0.2 & 1.5 & 3.2 & -1.2 & -4.9 & -7.3 & -4.3 & 4.2 & 1.1 & 0.4 & 6.3 & 11.1 & 2.0 & 7.6 \\
\hline Spain & -3.4 & -3.9 & -3.3 & -3.5 & -5.6 & -8.7 & -11.2 & -11.7 & -4.9 & 6.7 & 5.5 & 6.4 & 10.1 & 8.5 & 7.0 & 6.5 \\
\hline South Korea & -2.5 & -2.5 & -2.7 & 3.7 & 3.7 & -0.2 & -1.9 & -3.1 & -2.0 & 5.0 & 1.6 & 0.6 & 3.2 & 4.9 & 4.7 & 6.3 \\
\hline Iceland & -10.2 & -3.8 & 3.5 & -0.8 & -9.0 & -18.5 & -26.6 & -21.2 & -10.6 & 4.5 & 7.5 & 1.5 & -2.7 & 8.0 & 4.0 & 5.9 \\
\hline Sweden & 1.3 & 4.8 & 6.2 & 7.2 & 5.7 & 4.3 & 6.0 & 4.9 & 6.0 & 6.7 & 6.1 & 5.8 & 6.6 & 6.7 & 6.2 & 5.0 \\
\hline Hungary & -5.5 & -1.7 & 2.5 & -0.9 & -2.2 & 0.8 & 2.2 & -2.0 & -3.3 & 3.8 & 4.8 & 6.3 & 4.0 & 6.4 & 4.1 & 4.8 \\
\hline Portugal & -7.7 & -5.6 & -5.2 & -2.8 & -2.2 & -3.7 & -6.4 & -6.8 & -8.4 & -0.6 & 1.0 & 1.4 & 3.9 & 6.4 & 7.2 & 4.8 \\
\hline Italy & 0.8 & 3.3 & 2.4 & 2.2 & 2.7 & 2.6 & 1.1 & -0.8 & -0.1 & 3.5 & 0.9 & 0.7 & 2.5 & 3.7 & 4.8 & 4.2 \\
\hline China & 9.6 & 8.2 & 7.2 & 6.8 & 4.4 & 6.3 & 7.6 & 7.0 & 7.9 & 4.7 & 2.5 & 0.3 & 1.2 & 0.8 & 3.8 & 4.2 \\
\hline Luxembourg & 6.0 & 1.9 & 6.5 & 6.5 & 13.4 & 11.0 & 8.0 & 5.7 & 4.5 & 7.7 & 7.5 & 5.6 & 5.6 & 4.5 & 3.6 & 3.6 \\
\hline France & 2.5 & 2.9 & 4.3 & 4.8 & 3.9 & 3.2 & 2.3 & 2.2 & 2.2 & 6.4 & 6.0 & 4.1 & 3.6 & 3.1 & 2.9 & 3.3 \\
\hline Belgium & 4.1 & 3.3 & 4.5 & 5.3 & 3.4 & 4.7 & 1.7 & 1.9 & 0.1 & 4.3 & 5.7 & 3.0 & 4.2 & 2.7 & 2.4 & 3.0 \\
\hline Slovakia & 9.6 & 0.7 & 2.5 & 2.1 & -5.3 & -5.3 & -4.1 & -3.5 & -3.9 & 4.4 & 2.8 & -0.7 & 5.3 & 4.5 & 3.9 & 2.9 \\
\hline Austria & 1.4 & -0.1 & 3.5 & 3.4 & 6.9 & 4.8 & 5.9 & 5.2 & 6.1 & 8.0 & 7.3 & 4.2 & 3.7 & 3.3 & 5.1 & 2.9 \\
\hline Norway & -0.5 & 2.6 & 3.4 & 4.9 & 1.6 & 1.4 & -1.8 & -4.7 & -2.9 & 1.4 & 0.7 & -0.1 & -1.4 & -0.6 & 2.2 & 2.3 \\
\hline Estonia & -5.2 & -5.4 & -11.0 & -13.1 & -13.8 & -11.0 & -18.1 & -18.5 & -6.5 & 4.9 & 1.6 & 0.1 & -1.6 & -0.1 & 0.2 & 2.1 \\
\hline USA & -4.8 & -2.3 & 0.5 & 1.4 & 0.2 & -1.6 & -2.8 & -1.5 & 2.3 & 10.0 & 9.0 & 7.6 & 6.1 & 3.1 & 2.6 & 2.0 \\
\hline Poland & -3.0 & 1.7 & 2.1 & 3.6 & -0.4 & 1.4 & -0.4 & -4.6 & -3.1 & 3.2 & 1.9 & -0.4 & 0.0 & 2.8 & 1.3 & 2.0 \\
\hline Czech Rep. & -0.9 & 0.4 & 1.1 & 0.6 & -2.1 & 2.2 & 0.3 & -3.5 & 0.2 & 3.1 & 0.8 & 0.5 & 2.4 & 0.8 & 2.1 & 1.5 \\
\hline Finland & 1.5 & 4.3 & 4.6 & 2.6 & 4.2 & 1.2 & -0.1 & -1.2 & -2.0 & 4.5 & 3.9 & -0.8 & 0.2 & 0.9 & 1.0 & 0.5 \\
\hline Latvia & -1.0 & -4.0 & -3.3 & -5.7 & -10.7 & -11.3 & -20.5 & -20.1 & -8.5 & 17.0 & 10.6 & 0.2 & -2.8 & -1.8 & -0.4 & 0.5 \\
\hline Chile & -0.6 & -1.2 & 0.1 & -1.2 & -1.0 & -4.1 & -3.0 & -3.7 & -6.6 & 6.0 & 1.6 & -2.7 & -4.4 & -3.2 & 0.0 & 0.2 \\
\hline $\begin{array}{l}\text { United } \\
\text { Kingdom }\end{array}$ & -3.2 & -2.3 & -0.1 & 1.5 & 1.6 & 2.1 & 0.5 & 0.4 & 1.4 & 7.3 & 6.8 & 5.8 & 4.6 & 1.3 & 1.0 & -1.1 \\
\hline Canada & -0.2 & 1.6 & 1.9 & 1.3 & 1.5 & 0.3 & -0.4 & -1.0 & 0.0 & 0.9 & 1.2 & 0.5 & -1.1 & -1.3 & -1.8 & -1.9 \\
\hline Australia & -2.8 & -1.4 & -4.5 & -6.2 & -7.3 & -7.6 & -7.4 & -7.3 & -1.0 & 1.0 & 0.9 & 1.6 & -1.2 & -0.1 & -0.1 & -3.3 \\
\hline New Zealand & -5.0 & -2.2 & -5.4 & -5.8 & -8.4 & -11.5 & -12.2 & -11.1 & -8.2 & 0.3 & 4.7 & 1.1 & -1.8 & -2.4 & -3.1 & -3.9 \\
\hline
\end{tabular}

Source: The Author's own - the result of the following operation: $(S-I)=(G-T)+(X-Z)$. 
Table 7. Rates of economic growth in selected countries, 2000-2015

\begin{tabular}{|c|c|c|c|c|c|c|c|c|c|c|c|c|c|c|c|c|}
\hline Country & 2000 & 2001 & 2002 & 2003 & 2004 & 2005 & 2006 & 2007 & 2008 & 2009 & 2010 & 2011 & 2012 & 2013 & 2014 & 2015 \\
\hline Ireland & 9.9 & 6.1 & 5.6 & 3.7 & 6.7 & 5.8 & 5.9 & 3.8 & -4.4 & -4.6 & 2.0 & 0.0 & -1.1 & 1.1 & 8.5 & 7.8 \\
\hline China & 8.4 & 7.7 & 9.1 & 10.0 & 10.1 & 11.3 & 12.7 & 14.2 & 9.6 & 9.2 & 10.6 & 9.5 & 7.7 & 7.7 & 7.3 & 6.9 \\
\hline Czech Rep. & 4.3 & 3.1 & 1.6 & 3.6 & 4.9 & 6.4 & 6.9 & 5.5 & 2.7 & -4.8 & 2.3 & 2.0 & -0.8 & -0.5 & 2.7 & 4.5 \\
\hline Iceland & 4.7 & 3.8 & 0.3 & 2.4 & 8.1 & 6.7 & 5.0 & 9.4 & 1.5 & -6.9 & -3.6 & 2.0 & 1.2 & 4.4 & 1.9 & 4.2 \\
\hline Sweden & 4.7 & 1.6 & 2.1 & 2.4 & 4.3 & 2.8 & 4.7 & 3.4 & -0.6 & -5.2 & 6.0 & 2.7 & -0.3 & 1.2 & 2.6 & 4.1 \\
\hline Poland & 4.6 & 1.2 & 2.0 & 3.6 & 5.1 & 3.5 & 6.2 & 7.0 & 4.2 & 2.8 & 3.6 & 5.0 & 1.6 & 1.4 & 3.3 & 3.9 \\
\hline Slovakia & 1.2 & 3.3 & 4.5 & 5.4 & 5.3 & 6.8 & 8.5 & 10.8 & 5.6 & -5.4 & 5.0 & 2.8 & 1.7 & 1.5 & 2.6 & 3.8 \\
\hline Luxembourg & 9.5 & 4.6 & 3.6 & 1.4 & 4.4 & 3.2 & 5.1 & 8.4 & -0.8 & -5.4 & 5.8 & 2.0 & 0.0 & 4.2 & 4.7 & 3.5 \\
\hline New Zealand & 2.2 & 3.8 & 5.1 & 4.5 & 3.2 & 3.3 & 2.6 & 3.7 & -1.5 & 1.9 & 1.0 & 2.7 & 2.7 & 1.6 & 3.2 & 3.4 \\
\hline Spain & 0.0 & 4.0 & 2.9 & 3.2 & 3.2 & 3.7 & 4.2 & 3.8 & 1.1 & -3.6 & 0.0 & -1.0 & -2.9 & -1.7 & 1.4 & 3.2 \\
\hline Hungary & 4.2 & 3.8 & 4.5 & 3.8 & 5.0 & 4.4 & 3.9 & 0.4 & 0.9 & -6.6 & 0.7 & 1.7 & -1.6 & 2.1 & 4.0 & 3.1 \\
\hline Australia & 1.9 & 3.9 & 3.1 & 4.1 & 3.2 & 3.0 & 3.7 & 3.7 & 1.8 & 2.0 & 2.4 & 3.6 & 2.6 & 2.6 & 2.4 & 2.8 \\
\hline Latvia & 5.4 & 6.5 & 7.1 & 8.4 & 8.3 & 10.7 & 11.9 & 9.9 & -3.6 & -14.3 & -3.8 & 6.2 & 4.0 & 2.9 & 2.1 & 2.7 \\
\hline South Korea & 8.9 & 4.5 & 7.4 & 2.9 & 4.9 & 3.9 & 5.2 & 5.5 & 2.8 & 0.7 & 6.5 & 3.7 & 2.3 & 2.9 & 3.3 & 2.6 \\
\hline USA & 4.1 & 1.0 & 1.8 & 2.8 & 3.8 & 3.3 & 2.7 & 1.8 & -0.3 & -2.8 & 2.5 & 1.6 & 2.2 & 1.7 & 2.4 & 2.6 \\
\hline Israel & 8.8 & 0.1 & -0.2 & 1.1 & 5.0 & 4.2 & 5.7 & 6.2 & 3.0 & 1.4 & 5.7 & 5.1 & 2.4 & 4.4 & 3.2 & 2.5 \\
\hline Chile & 5.1 & 3.3 & 2.7 & 3.8 & 7.0 & 6.2 & 5.7 & 5.2 & 3.3 & -1.0 & 5.8 & 5.8 & 5.5 & 4.0 & 1.9 & 2.3 \\
\hline Slovenia & 4.2 & 2.9 & 3.8 & 2.8 & 4.4 & 4.0 & 5.7 & 6.9 & 3.3 & -7.8 & 1.2 & 0.6 & -2.7 & -1.1 & 3.1 & 2.3 \\
\hline United Kingdom & 3.7 & 2.7 & 2.4 & 3.5 & 2.5 & 3.0 & 2.5 & 2.6 & -0.6 & -4.3 & 1.9 & 1.5 & 1.3 & 1.9 & 3.1 & 2.2 \\
\hline Netherlands & 4.2 & 2.1 & 0.1 & 0.3 & 2.0 & 2.2 & 3.5 & 3.7 & 1.7 & -3.8 & 1.4 & 1.7 & -1.1 & -0.2 & 1.4 & 2.0 \\
\hline Germany & 3.0 & 1.7 & 0.0 & -0.7 & 1.2 & 0.7 & 3.7 & 3.3 & 1.1 & -5.6 & 4.1 & 3.7 & 0.5 & 0.5 & 1.6 & 1.7 \\
\hline Denmark & 3.7 & 0.8 & 0.5 & 0.4 & 2.7 & 2.3 & 3.9 & 0.9 & -0.5 & -4.9 & 1.9 & 1.3 & 0.2 & 0.9 & 1.7 & 1.6 \\
\hline Norway & 3.2 & 2.1 & 1.4 & 0.9 & 4.0 & 2.6 & 2.4 & 2.9 & 0.4 & -1.6 & 0.6 & 1.0 & 2.7 & 1.0 & 1.9 & 1.6 \\
\hline Belgium & 3.6 & 0.8 & 1.8 & 0.8 & 3.6 & 2.1 & 2.5 & 3.4 & 0.7 & -2.3 & 2.7 & 1.8 & 0.1 & -0.1 & 1.7 & 1.5 \\
\hline Portugal & 3.8 & 1.9 & 0.8 & -0.9 & 1.8 & 0.8 & 1.6 & 2.5 & 0.2 & -3.0 & 1.9 & -1.8 & -4.0 & -1.1 & 0.9 & 1.5 \\
\hline Estonia & 10.6 & 6.3 & 6.1 & 7.4 & 6.3 & 9.4 & 10.3 & 7.7 & -5.4 & -14.7 & 2.3 & 7.6 & 4.3 & 1.4 & 2.8 & 1.4 \\
\hline France & 3.9 & 2.0 & 1.1 & 0.8 & 2.8 & 1.6 & 2.4 & 2.4 & 0.2 & -2.9 & 2.0 & 2.1 & 0.2 & 0.6 & 0.6 & 1.3 \\
\hline Austria & 3.4 & 1.4 & 1.7 & 0.8 & 2.7 & 2.1 & 3.4 & 3.6 & 1.5 & -3.8 & 1.9 & 2.8 & 0.7 & 0.1 & 0.6 & 1.0 \\
\hline Canada & 5.2 & 1.8 & 3.0 & 1.8 & 3.1 & 3.2 & 2.6 & 2.1 & 1.0 & -2.9 & 3.1 & 3.1 & 1.7 & 2.5 & 2.6 & 0.9 \\
\hline Switzerland & 3.9 & 1.4 & 0.1 & 0.0 & 2.8 & 3.0 & 4.0 & 4.1 & 2.3 & -2.1 & 3.0 & 1.8 & 1.0 & 1.8 & 2.0 & 0.8 \\
\hline Italy & 3.7 & 1.8 & 0.2 & 0.2 & 1.6 & 0.9 & 2.0 & 1.5 & -1.1 & -5.5 & 1.7 & 0.6 & -2.8 & -1.7 & 0.1 & 0.7 \\
\hline Japan & 2.3 & 0.4 & 0.3 & 1.7 & 2.4 & 1.3 & 1.7 & 2.2 & -1.0 & -5.5 & 4.7 & -0.5 & 1.7 & 1.4 & 0.0 & 0.5 \\
\hline Finland & 5.6 & 2.6 & 1.7 & 2.0 & 3.9 & 2.8 & 4.1 & 5.2 & 0.7 & -8.3 & 3.0 & 2.6 & -1.4 & -0.8 & -0.7 & 0.2 \\
\hline Greece & 3.9 & 4.1 & 3.9 & 5.8 & 5.1 & 0.6 & 5.7 & 3.3 & -0.3 & -4.3 & -5.5 & -9.1 & -7.3 & -3.2 & 0.4 & -0.2 \\
\hline Russia & 10.0 & 5.1 & 4.7 & 7.3 & 7.2 & 6.4 & 8.2 & 8.5 & 5.2 & -7.8 & 4.5 & 4.3 & 3.5 & 1.3 & 0.7 & -3.7 \\
\hline
\end{tabular}

Source: The Author's own, based on the OECD data. Countries are ranked according to their rate of growth in 2015. 
Table 8. Average rates of growth of budgetary deficit countries vs. budgetary surplus countries

\begin{tabular}{|l|c|c|c|c|c|c|c|c|}
\hline \multicolumn{1}{|c|}{ Specification } & $\mathbf{2 0 0 0}$ & $\mathbf{2 0 0 1}$ & $\mathbf{2 0 0 2}$ & $\mathbf{2 0 0 3}$ & $\mathbf{2 0 0 4}$ & $\mathbf{2 0 0 5}$ & $\mathbf{2 0 0 6}$ & $\mathbf{2 0 0 7}$ \\
\hline deficit countries & 4.36 & 2.79 & 2.38 & 2.57 & 4.18 & 3.65 & 4.66 & 4.44 \\
\hline surplus countries & 5.51 & 3.29 & 3.88 & 3.90 & 4.71 & 4.35 & 5.07 & 5.15 \\
\hline $\begin{array}{l}\text { how many times the rate of growth } \\
\text { is higher in the surplus countries }\end{array}$ & 1.3 & 1.2 & 1.6 & 1.5 & 1.1 & 1.2 & 1.1 & 1.2 \\
\hline
\end{tabular}

\begin{tabular}{|l|c|c|c|c|c|c|c|c|}
\hline \multicolumn{1}{|c|}{ Specification } & $\mathbf{2 0 0 8}$ & $\mathbf{2 0 0 9}$ & $\mathbf{2 0 1 0}$ & $\mathbf{2 0 1 1}$ & $\mathbf{2 0 1 2}$ & $\mathbf{2 0 1 3}$ & $\mathbf{2 0 1 4}$ & $\mathbf{2 0 1 5}$ \\
\hline deficit countries & 0.50 & -4.35 & 2.20 & 1.66 & 0.23 & 1.00 & 2.28 & 2.30 \\
\hline surplus countries & 1.82 & 1.83 & 4.60 & 4.46 & 3.20 & 3.95 & 2.67 & 2.39 \\
\hline $\begin{array}{l}\text { how many times the rate of growth } \\
\text { is higher in the surplus countries }\end{array}$ & 3.6 & - & 2.1 & 2.7 & 14.1 & 4.0 & 1.2 & 1.0 \\
\hline
\end{tabular}

\section{Source: The Author's own.}

the labor market (and of unemployment in particular), money resources, the structure of financial markets, inflation, the stability of interest rates, and so on. This is illustrated by Figure 1, which presents a bilateral nature of causal relationships and the

Figure 1. Interdependencies of twin balances

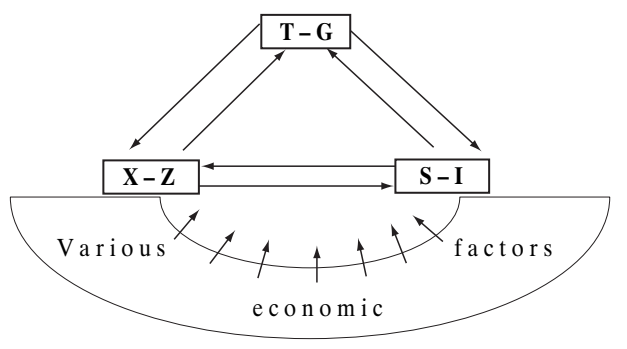

fact that all the elements involved are determined by plenty of economic factors.

Despite these relationships being multilateral, some interesting findings result from an econometric analysis limited to correlations and to coefficients of regression.

This way, coefficients of correlation between individual balances were defined, as well as between the balances and economic growth measured with the rate of GDP growth.

Quite interesting findings stem from an analysis of correlations occurring over that period between the figures examined. Correlations were specified between individual balances as well as between the balances and economic growth measured with the GDP growth rate (Table 9).

Table 9. Correlations

\begin{tabular}{|l|c|c|c|c|c|c|c|c|}
\hline Specification & $\mathbf{2 0 0 0}$ & $\mathbf{2 0 0 1}$ & $\mathbf{2 0 0 2}$ & $\mathbf{2 0 0 3}$ & $\mathbf{2 0 0 4}$ & $\mathbf{2 0 0 5}$ & $\mathbf{2 0 0 6}$ & $\mathbf{2 0 0 7}$ \\
\hline $\begin{array}{l}\text { correlation of budget balance (T - G) } \\
\text { and current accounts (X-Z) }\end{array}$ & $\mathbf{0 . 5 3}$ & $\mathbf{0 . 7 1}$ & $\mathbf{0 . 5 5}$ & $\mathbf{0 . 3 7}$ & $\mathbf{0 . 3 3}$ & $\mathbf{0 . 3 8}$ & $\mathbf{0 . 3 4}$ & $\mathbf{0 . 4 2}$ \\
\hline $\begin{array}{l}\text { correlation of budget balance (T - G) } \\
\text { and the balance (S - I) }\end{array}$ & -0.22 & -0.02 & -0.25 & -0.28 & -0.24 & -0.27 & -0.21 & -0.12 \\
\hline $\begin{array}{l}\text { correlation of current account balance } \\
\text { X - Z) } \\
\text { and the balance (S - I) }\end{array}$ & $\mathbf{0 . 7 1}$ & $\mathbf{0 . 6 9}$ & $\mathbf{0 . 6 6}$ & $\mathbf{0 . 7 9}$ & $\mathbf{0 . 8 4}$ & $\mathbf{0 . 7 9}$ & $\mathbf{0 . 8 5}$ & $\mathbf{0 . 8 5}$ \\
\hline $\begin{array}{l}\text { correlation between balance (T - G) } \\
\text { and GDP growth }\end{array}$ & 0.24 & 0.05 & 0.17 & 0.10 & 0.24 & 0.22 & 0.03 & 0.18 \\
\hline $\begin{array}{l}\text { correlation between balance (X-Z) } \\
\text { and GDP growth }\end{array}$ & $\mathbf{0 . 2 9}$ & -0.16 & -0.24 & $-\mathbf{0 . 3 6}$ & -0.21 & -0.25 & -0.23 & -0.09 \\
\hline $\begin{array}{l}\text { correlation between balance (S - I) } \\
\text { and GDP growth }\end{array}$ & 0.14 & -0.27 & $-\mathbf{0 . 4 2}$ & $-\mathbf{0 . 4 4}$ & $-\mathbf{0 . 3 5}$ & $-\mathbf{0 . 4 0}$ & -0.26 & -0.20 \\
\hline
\end{tabular}


Table 9 cont

\begin{tabular}{|l|c|c|c|c|c|c|c|c|}
\hline \multicolumn{1}{|c|}{ Specification } & $\mathbf{2 0 0 8}$ & $\mathbf{2 0 0 9}$ & $\mathbf{2 0 1 0}$ & $\mathbf{2 0 1 1}$ & $\mathbf{2 0 1 2}$ & $\mathbf{2 0 1 3}$ & $\mathbf{2 0 1 4}$ & $\mathbf{2 0 1 5}$ \\
\hline $\begin{array}{l}\text { correlation of budget balance (T - G) } \\
\text { and current accounts (X - Z) }\end{array}$ & $\mathbf{0 . 8 0}$ & $\mathbf{0 . 7 2}$ & $\mathbf{0 . 5 5}$ & $\mathbf{0 . 6 7}$ & $\mathbf{0 . 5 3}$ & $\mathbf{0 . 3 3}$ & $\mathbf{0 . 5 4}$ & $\mathbf{0 . 4 2}$ \\
\hline $\begin{array}{l}\text { correlation of budget balance (T - G) } \\
\text { and the balance (S - I) }\end{array}$ & 0.21 & $\mathbf{- 0 . 2 8}$ & $\mathbf{- 0 . 6 2}$ & $\mathbf{- 0 . 4 6}$ & $\mathbf{- 0 . 4 2}$ & $\mathbf{- 0 . 5 8}$ & -0.24 & -0.19 \\
\hline $\begin{array}{l}\text { correlation of current account balance } \\
\text { X - Z) } \\
\text { and the balance (S - I) }\end{array}$ & $\mathbf{0 . 7 5}$ & $\mathbf{0 . 4 6}$ & $\mathbf{0 . 3 1}$ & $\mathbf{0 . 3 6}$ & $\mathbf{0 . 5 5}$ & $\mathbf{0 . 5 8}$ & $\mathbf{0 . 6 8}$ & $\mathbf{0 . 8 1}$ \\
\hline $\begin{array}{l}\text { correlation between balance (T - G) } \\
\text { and GDP growth }\end{array}$ & 0.18 & 0.20 & $\mathbf{0 . 3 3}$ & $\mathbf{0 . 4 7}$ & $\mathbf{0 . 4 6}$ & $\mathbf{0 . 4 3}$ & 0.11 & 0.17 \\
\hline $\begin{array}{l}\text { correlation between balance (X-Z) } \\
\text { and GDP growth }\end{array}$ & 0.27 & -0.10 & $\mathbf{0 . 3 4}$ & 0.27 & -0.02 & 0.02 & 0.05 & 0.07 \\
\hline $\begin{array}{l}\text { correlation between balance (S - I) } \\
\text { and GDP growth }\end{array}$ & 0.25 & $\mathbf{- 0 . 3 9}$ & -0.06 & -0.28 & $\mathbf{- 0 . 4 7}$ & $\mathbf{- 0 . 3 5}$ & -0.03 & -0.03 \\
\hline
\end{tabular}

Source: The Author's own. Values meeting the criterion of statistical significance printed in bold these values give no reason to reject the hypothesis about the actual lack of correlation, at the level of significance 0.0518 .

To measure the correlation strength, Pearson linear correlation coefficient was applied, which, obviously, only indicates a mutual symmetrical relation without showing the direction of dependencies. Considering this, directional coefficients of linear regression function were also cal- culated for $y=\beta_{0}+\beta_{1} x$ and $x=\beta_{0}+\beta_{1} y$. By comparing directional coefficients $\beta_{1}$ for a given figure vs. another figure and the other way round we are able to conclude which one has stronger influence as albeit only statistical - reason for the other figure.

Table 10. Regressions

\begin{tabular}{|l|c|c|c|c|c|c|c|c|}
\hline \multicolumn{1}{|c|}{ Specification } & $\mathbf{2 0 0 0}$ & $\mathbf{2 0 0 1}$ & $\mathbf{2 0 0 2}$ & $\mathbf{2 0 0 3}$ & $\mathbf{2 0 0 4}$ & $\mathbf{2 0 0 5}$ & $\mathbf{2 0 0 6}$ & $\mathbf{2 0 0 7}$ \\
\hline $\begin{array}{l}\text { regression of budget balance }(\mathrm{T}-\mathrm{G}) \\
\text { vs. current accounts }(\mathrm{X}-\mathrm{Z})\end{array}$ & $\mathbf{0 . 3 8}$ & $\mathbf{0 . 5 2}$ & $\mathbf{0 . 4 3}$ & $\mathbf{0 . 2 4}$ & $\mathbf{0 . 1 9}$ & $\mathbf{0 . 2 4}$ & $\mathbf{0 . 1 9}$ & $\mathbf{0 . 2 2}$ \\
\hline $\begin{array}{l}\text { regression of current accounts }(\mathrm{X}-\mathrm{Z}) \\
\text { vs. budget }(\mathrm{T}-\mathrm{G})\end{array}$ & $\mathbf{0 . 7 3}$ & $\mathbf{0 . 9 8}$ & $\mathbf{0 . 7 2}$ & $\mathbf{0 . 5 8}$ & $\mathbf{0 . 5 9}$ & $\mathbf{0 . 6 0}$ & $\mathbf{0 . 6 3}$ & $\mathbf{0 . 8 0}$ \\
\hline $\begin{array}{l}\text { regression of budget balance (T -G) } \\
\text { vs. the savings-investments balance (S-I) }\end{array}$ & -0.18 & -0.02 & -0.23 & -0.18 & -0.14 & -0.18 & -0.12 & -0.07 \\
\hline $\begin{array}{l}\text { regression of balance }(\mathrm{S}-\mathrm{I}) \\
\text { vs. budget (T-G) }\end{array}$ & -0.27 & -0.02 & -0.28 & -0.42 & -0.41 & -0.40 & -0.37 & -0.20 \\
\hline $\begin{array}{l}\text { regression of current accounts }(\mathrm{X}-\mathrm{Z}) \\
\text { vs. the savings-investments balance }(\mathrm{S}-\mathrm{I})\end{array}$ & $\mathbf{0 . 8 2}$ & $\mathbf{0 . 9 8}$ & $\mathbf{0 . 7 7}$ & $\mathbf{0 . 8 2}$ & $\mathbf{0 . 8 6}$ & $\mathbf{0 . 8 2}$ & $\mathbf{0 . 8 8}$ & $\mathbf{0 . 9 3}$ \\
\hline $\begin{array}{l}\text { regression of balance }(\mathrm{S}-\mathrm{I}) \\
\text { vs. current accounts }(\mathrm{X}-\mathrm{Z})\end{array}$ & $\mathbf{0 . 6 2}$ & $\mathbf{0 . 4 8}$ & $\mathbf{0 . 5 7}$ & $\mathbf{0 . 7 6}$ & $\mathbf{0 . 8 1}$ & $\mathbf{0 . 7 6}$ & $\mathbf{0 . 8 1}$ & $\mathbf{0 . 7 8}$ \\
\hline $\begin{array}{l}\text { regression of budget balance }(\mathrm{T}-\mathrm{G}) \\
\text { vs. GDP growth }\end{array}$ & 0.43 & 0.10 & 0.29 & 0.13 & 0.45 & 0.39 & 0.06 & 0.26 \\
\hline $\begin{array}{l}\text { regression of GDP growth vs. } \\
\text { budget balance (T - G) }\end{array}$ & 0.13 & 0.02 & 0.10 & 0.07 & 0.12 & 0.13 & 0.02 & 0.13 \\
\hline
\end{tabular}

Wydział Zarządzania UW https://doi.org/10.7172/1733-9758.2018.29.7 
Table 10 cont.

\begin{tabular}{|l|c|c|c|c|c|c|c|c|}
\hline \multicolumn{1}{|c|}{ Specification } & $\mathbf{2 0 0 0}$ & $\mathbf{2 0 0 1}$ & $\mathbf{2 0 0 2}$ & $\mathbf{2 0 0 3}$ & $\mathbf{2 0 0 4}$ & $\mathbf{2 0 0 5}$ & $\mathbf{2 0 0 6}$ & $\mathbf{2 0 0 7}$ \\
\hline $\begin{array}{l}\text { regression of the current accounts (X-Z) } \\
\text { vs. GDP growth }\end{array}$ & $\mathbf{0 . 7 2}$ & -0.47 & -0.53 & $\mathbf{- 0 . 7 7}$ & -0.69 & -0.67 & -0.74 & -0.24 \\
\hline $\begin{array}{l}\text { regression of growth vs. } \\
\text { the current accounts balance (X - Z) }\end{array}$ & $\mathbf{0 . 1 2}$ & -0.05 & -0.11 & $\mathbf{- 0 . 1 7}$ & -0.06 & -0.09 & -0.07 & -0.03 \\
\hline $\begin{array}{l}\text { regression of balance (S - I) } \\
\text { vs. GDP growth }\end{array}$ & 0.29 & -0.57 & $\mathbf{- 0 . 8 2}$ & $\mathbf{- 0 . 9 1}$ & $\mathbf{- 1 . 1 4}$ & $\mathbf{- 1 . 0 6}$ & -0.80 & -0.49 \\
\hline $\begin{array}{l}\text { regression of GDP growth } \\
\text { vs. the savings-investments balance (S - I) }\end{array}$ & 0.06 & -0.13 & $\mathbf{- 0 . 2 2}$ & $\mathbf{- 0 . 2 2}$ & $\mathbf{- 0 . 1 1}$ & $\mathbf{- 0 . 1 5}$ & -0.08 & -0.08 \\
\hline
\end{tabular}

\begin{tabular}{|c|c|c|c|c|c|c|c|c|}
\hline Specification & 2008 & 2009 & 2010 & 2011 & 2012 & 2013 & 2014 & 2015 \\
\hline $\begin{array}{l}\text { regression of budget balance }(T-G) \\
\text { vs. current accounts }(X-Z)\end{array}$ & 0.54 & 0.67 & 0.67 & 0.70 & 0.49 & 0.33 & 0.41 & 0.25 \\
\hline $\begin{array}{l}\text { regression of current accounts }(X-Z) \\
\text { vs. budget }(T-G)\end{array}$ & 1.19 & 0.78 & 0.46 & 0.63 & 0.58 & 0.33 & 0.72 & 0.70 \\
\hline $\begin{array}{l}\text { regression of budget balance ( } \mathrm{T} \\
\text { vs. the savings-investments balan }\end{array}$ & 0.23 & -0.36 & -0.70 & -0.58 & -0.41 & -0.50 & -0.21 & -0.12 \\
\hline $\begin{array}{l}\text { regression of balance }(S-I) \\
\text { vs. budget }(T-G)\end{array}$ & 0.19 & -0.22 & -0.54 & -0.37 & -0.42 & -0.67 & -0.28 & -0.30 \\
\hline $\begin{array}{l}\text { regression of current accounts }(\mathrm{X}-\mathrm{Z}) \\
\text { vs. the savings-investments balance }(\mathrm{S}-\mathrm{I})\end{array}$ & 1.23 & 0.64 & 0.30 & 0.42 & 0.59 & 0.50 & 0.79 & 0.88 \\
\hline $\begin{array}{l}\text { regression of balance }(\mathrm{S}-\mathrm{I}) \\
\text { vs. current accounts }(\mathrm{X}-\mathrm{Z})\end{array}$ & 0.46 & 0.33 & 0.33 & 0.30 & 0.51 & 0.67 & 0.59 & 0.75 \\
\hline $\begin{array}{l}\text { regression of budget balance }(T-G) \\
\text { vs. GDP growth }\end{array}$ & 0.34 & 0.21 & 0.72 & 0.79 & 0.69 & 0.86 & 0.17 & 0.21 \\
\hline $\begin{array}{l}\text { regression of GDP growth vs. } \\
\text { budget balance }(T-G)\end{array}$ & 0.10 & 0.18 & 0.15 & 0.28 & 0.30 & 0.21 & 0.07 & 0.13 \\
\hline $\begin{array}{l}\text { regression of the current accounts }(\mathrm{X}-\mathrm{Z}) \\
\text { vs. GDP growth }\end{array}$ & 0.75 & -0.11 & 0.61 & 0.42 & -0.03 & 0.05 & 0.11 & 0.15 \\
\hline $\begin{array}{l}\text { regression of growth vs. } \\
\text { the current accounts balance }(\mathrm{X}-\mathrm{Z})\end{array}$ & 0.10 & -0.08 & 0.19 & 0.17 & -0.01 & 0.01 & 0.02 & 0.03 \\
\hline $\begin{array}{l}\text { regression of balance }(\mathrm{S}-\mathrm{I}) \\
\text { vs. GDP growth }\end{array}$ & 0.41 & -0.33 & -0.11 & -0.37 & -0.72 & -0.82 & -0.06 & -0.06 \\
\hline $\begin{array}{l}\text { regression of GDP growth } \\
\text { vs. the savings-investments balance }(\mathrm{S}-\mathrm{I})\end{array}$ & 0.15 & -0.46 & -0.03 & -0.21 & -0.31 & -0.15 & -0.02 & -0.02 \\
\hline
\end{tabular}

Source: The Author's own. * By regression we understood a directional coefficient $\beta_{1}$ of regression function - i.e. the relation of co-variance of the two figures to the variance of the figure regarded as an explanatory variable. Values meeting the criterion of statistical significance printed in bold - these values give no reason to reject the hypothesis that $\beta_{1}=0$, which would mean that there is no influence of the explanatory variable on the explained variable, at the level of significance 0.05 . 
The above results enable us to draw the following conclusions:

1. There exists an evident positive correlation between the state of budget and that of current account. In other words, a budgetary deficit is accompanied by a current account deficit and a budgetary surplus is accompanied by a surplus on the current account.

2. For most of the period under examination, a phenomenon that was positive and much stronger was regression of the current account vs. the budget, i.e. it was the budget result that influenced the result of the current account rather than the other way round, except for the years 2010, 2011 and 2013, i.e. the years following the crisis.

3. A negative (apart from the crisis year 2008 and the time just after the crisis began), but relatively weak (markedly stronger only in the post-crisis years 2010-2013) correlation occurred between the state of budget defined by $(T-G)$ and the balance of savings - investments $(\mathrm{S}-\mathrm{I})$ in the private sector. Accordingly, the deficit $((T-G)<0)$ tended to be accompanied by a surplus of savings $((\mathrm{S}-\mathrm{I})>0)-$ absorbed by the State loan instruments, while a budgetary surplus $((T-G)>0)$ was accompanied by a surplus of investments compared to savings $((\mathrm{S}-\mathrm{I})<0)$.

Therefore, statistical data affirm a logical relation between budgetary deficit and excess liquidity in the financial sector.

However, it should be observed that this relation is not very explicit, the one between the budget and the current account being more pronounced.

4. Until the time of the crisis the regression of balance $(\mathrm{S}-\mathrm{I})$ with respect to the budget was obviously stronger than the budget explained by the balance $(\mathrm{S}-\mathrm{I})$. Then, from the time the crisis began, i.e. from 2008, regression of budget vs. (S - I) is much more definite. This confirms that the process of overcoming the crisis was accompanied by a strong dependence of the prevailing deficit budgets on the surplus of savings vs. investments. Characteristically, from 2012 onwards we are witnessing a return toward the former relation: regression $(\mathrm{S}-\mathrm{I})$ vs. the budget becomes stronger again. It should be observed that it was 2008 when the first evident symptoms of the crisis appeared, several countries already experienced recession, while almost all followed suit in 2009, just 6 of 35 countries managing to retain a positive growth rate.

5. There was a relatively strong correlation - except for the post-crisis years 2010 and 2011 - between the current account balance $(\mathrm{X}-\mathrm{Z})$ and the balance $(\mathrm{S}-\mathrm{I})$. This indicated that the surplus on the current account was usually accompanied by a surplus of savings, and respectively, a deficit on the current account was accompanied by a deficit of savings.

6. On the other hand, regression of current account vs. the balance (S-I) usually tended to be stronger than that of the balance $(S-I)$ vs. the current account. A surplus on the current account was more likely to be explained by the state of the surplus of savings (or, in deficit conditions - by the deficit); the years 2010 and 2013 being an exception in this respect.

7. All those balances seemed to only feebly correlate with economic growth. In particular, and quite interestingly, the correlation between the state of the State finance and growth was usually weak, apart from the years 2011-2013, when it approached $r=0.5$. One could argue, therefore, that while this correlation was positive, we are still short of any firm ground to support the statement that the budgetary surplus favors the achievement of economic growth - although, as mentioned before, the average rates of growth of the surplus countries were higher.

8. However, the coefficients of regression indicate that the state of the budget was explained by economic growth rather that the opposite way: in all the years over the period in question the coefficient of regression for the budget vs. the growth was markedly higher than that of growth vs. the budget.

This supports the statement put forth before, that a budgetary surplus is an effect of growth rather than growth resulting from a budgetary surplus.

9. The correlation between the state of current account and growth was generally weak, especially in the years preceding the crisis. This suggests that before the crisis it hardly seemed to favor the growth of the surplus on the current account, while after the crisis its influence became negative or perhaps neutral. 
10. This correlation was usually negative apart from the year 2000 and the key crisis year 2009; from 2012 on it practically fell down to zero. The regression coefficients indicate that the state of current account rather tended to be explained by the state of economic growth, but still the coefficients, just as the correlation, of course, were negative, so high growth was leading to a deficit on the current account, i.e. to a surplus of import, which is an obvious consequence of import intensity of an economy featuring a high rate of growth (however, as already mentioned, that relation virtually vanished after 2012).

11. The correlation between the balance of savings-investments and the rate of growth was generally weak and mostly negative. This suggests that, contrary to a popular opinion, a surplus of savings never really favored economic growth. If the coefficient of correlation achieved a higher, i.e. statistically significant (negative), value, this happened in the pre-crisis years 2002-2005 as well as soon as the crisis appeared, i.e. 2009 and 2012-2013. That its value was negative is quite obvious, because the very emergence of a surplus of savings means the state of advantage of delayed demand over the economy's ability to absorb the same, which is typical to states of low growth of even to recession, while any higher rate of growth of course implies investments and therefore a potentially negative value of the balance $(\mathrm{S}-\mathrm{I})$.

What seems characteristic, however, is that a positive correlation only occurred in the year 2000 and in the midst of the crisis, in 2009 - and still its value was low, statistically insignificant in terms of statistic deduction, so this really advocates the hypothesis about an actual lack of correlation ${ }^{19}$. The same thing, quite naturally, is confirmed by the logical analysis of the role of savings in the economy, known as the savings paradox (Laski, 2015, pp. 73-76). It is also noteworthy that the coefficient of correlation increased visibly in 2003, i.e. the year preceding the accession (other coefficients showed a similar change).

12. The coefficients of regression confirm (with 2009 being an exception as a crisis year) that the state of balance $(\mathrm{S}-\mathrm{I})$ followed economic growth and was explained by it rather than the other way round, i.e. economic growth being determined by the state of the savings - investments balance.

13. Some conclusions are reduced by the lack of statistical significance.

The statistical data presented here corroborate the fundamental conclusion, expressed before, that the condition of the State budget is in strict relation with that of two other balances, but those relations are quite complex and - very importantly - it would be plainly wrong to put forth naïve neoliberal theses and use them as grounds upon which concepts of the fiscal pact then rely or any similar bureaucratic initiatives. Likewise, it would also be wrong to argue that the objective to follow is to eliminate budgetary deficits and to strive for a surplus because - purportedly - a surplus leads to achievement of a higher rate of growth. The coefficients of regression confirm that the dependence of the state of budget on the rate of growth is stronger that the opposite relation. In consequence, the same dependence clearly indicates that high economic growth countries were achieving, thanks to that growth, budgetary surplus, which was usually related with a surplus on their current account, the latter one, in turn, being accompanied by foreign expansion and capital export.

The crucial conclusion stemming from the present analysis is that economic relationships are much more complex than they might look to proponents of neoliberal ideology - and that the economy should be looked upon considering the context of a variety of processes which determine the three balances working behind the economic equilibrium.

\section{Endnotes}

1 Algebraic identity is an equation which is true no matter which values are chosen as its variables.

2 Actually, reasons to make savings are plenty some basic ones being defined by J. M. Keynes as relating to: (1) prudence (to be able to fund unforeseen future expenses and to safeguard one's living standard once retired); (2) consumption (to purchase, in the future, more expensive durable goods); (3) transactions, maintenance of liquidity - (to maintain the ability to serve 
future obligations); (4) speculative (in order to have means enabling risky investments made to increase the value of the property collected). Importantly, and contrary to a popular belief, the interest rate on deposits is not at all the most significant factor motivating people to make savings. Instead, quite important in this respect are fiscal incentives as well as cultural patterns and standards which shape people's propensity to save money (for example, the middle class cult of foresight and prudence).

3 It should be reiterated from the trivia of economics that the GDP is a stream category and its volume is described in three ways: (1) as a sum of expenses - it constitutes the sum of consumption, investments, state expenditure made by the government (apart from transfers) and changes in the level of reserves; (2) as a sum of income - from labor, from capital, state revenues and appreciation; (3) as a sum of products - it is defined as the summed up value of all final goods and services generated - subtracted from the total value of goods and services generated (understood as global production) are those goods and services which were consumed to generate that production, i.e. indirect goods. All those elements have a stream nature, whereas savings, understood as a "decrement" in the stream of income and unmade outlays, are the difference between the income and the consumption and means transferred to the state, i.e. taxes, then used to fund the state expenditure. As rightly observed by G. W. Kołodko, the Gross Domestic Product calculated this way, together with all its components, out of their very nature fails to include a number of significant areas of human and social activity. "And, after all, it is on how one measures things that where one heads really depends" - adds Kołodko. Today's world may be described as "post-GDP reality", i.e. one in which the GDP no longer suffices to measure commercial activity. The GDP is very imperfect and, accordingly, new economic reality of the $21^{\text {st }}$ century requires new, more sophisticated measuring methods - see: Kołodko, 2013.

4 The formal definition applied in statistics of GUS (Statistics Poland) classifies investments in the category "investment outlays" as financial or material outlays the aim of which is to generate new fixed assets or an improvement (reconstruction, extension, modernization) of already-existing fixed property, or outlays made on the socalled first equipment of investments. In English we speak about Gross Fixed Capital Formation (GFCF), defined as the acquisition (including purchases of new or second-hand assets) and creation of assets by producers for their own use, minus disposals of produced fixed assets).

5 Wikipedia, under heading "saving" (in Polish): https://pl.wikipedia.org/wiki/Oszcz\%C4\%99 dzanie Unfortunately, many definitions published on the Internet are flawed at best, often prepared by persons of scarce competence. This is the key weakness of that web encyclopedia, developed by a kind of mass movement, instead of being crafted by eminent experts in respective areas, renowned and reliable, as is in the case of proper, traditional, printed encyclopedia.

6 Ibidem.

7 This may be seen as a kind of paradox, considering that any balance consists of an active side and another side which is passive. However, whilst cash is recorded by businesses as their assets, it still remains passive as it rests in the coffers doing no work. It should be observed that the only institution which keeps cash recorded as liabilities is the central bank - one could say that this makes its peculiar liability toward the society, but still this is cash in circulation, operating outside the central bank.

8 And this may be the reason of a (seemingly) low level of investments recorded - accompanied by decreasing deposits kept by businesses.

9 The second leg is formed by the pool of money in circulation - this is the "transaction leg". See: Żyżyński, 2014.

10 According to the data from the National Bank of Poland.

11 The obligatory reserve $(3.5 \%)$ is withdrawn from both $a$ vista current accounts and fixedterm deposits.

$12 \mathrm{M} 3$, a parameter used to analyze the condition of the currency, differs from M2 by a mere PLN 12 bn - these are repurchase instruments and some debt papers in the monetary market.

13 After all, while buying anything we hand over some part of our rights to acquire goods and services to the seller.

14 However, every expense obviously makes a cost. And every expense decreases the pool of remaining spending potential - for example, costs of a house rent decrease the payers' potential demand for other products.

15 Revenues from privatization have also been used to finance the deficit.

16 The so-called Big-Mac index, published by "The Economist", provides quite good approximation of the exchange rate according to the purchasing power parity. This index is rather representative and generally worth of attention because at the same time the disparity of that rate in relation to the market-based exchange rate of the U.S. dollar (or euro) is published as well.

17 According to the Author of this study, a high cost of the import input, under conditions of high import intensity of both production and investments, is an important factor diminishing wages earned by workers.

18 A reservation should be made here that the application of methods of statistical deduction is actually limited in this case, because the sam- 
ple of countries has not been chosen at random. Accordingly, conclusions concerning statistical hypotheses must not be regarded as the basis for making generalizations about all the countries in question and for building any sort of universa theory. On the same account, this gives no basis for rejecting the statistically insignificant findings altogether (here printed in plain characters).

As the countries included were not chosen at random, but instead they are a group of the OECD member states corrected by the elimination of some countries and the inclusion of other ones, it can be said that it is a nonprobability sample rather than a random sample. In fact, the pool here in question is some complete and purposefully defined group, which makes examination of statistical significance unjustified in this case. Accordingly, we may consider all the coefficients of correlation here as real values for the population, while the statistical significance has only approximate meaning, answering the question how the coefficients calculated should be interpreted if it was a random sample in the first place.

19 To put this correctly, there are no (statistical) reasons to reject the hypothesis about the actua lack of correlation - notwithstanding all above reservations concerning the applicability of such conclusions.

\section{References}

Czekaj, J., \& Dresler, Z. (2005). Zarzadzanie finansami przedsiębiorstw [Corporate finance management]. Warszawa: PWN.

ECB. (2019). Financial Stability Review. Retrieved from: https://www.ecb.europa.eu/pub/fsr/html/ index.en.html.

Galbraith, J.K. (2000). Gospodarka niewinnego oszustwa: prawda naszych czasów [The economy of an innocent deceit: The truth of our time]. Warszawa: MT Biznes Publishing.

Kołodko, G.W. (2013). Dokad zmierza świat. Ekonomia polityczna przysztości [Where the world $i$ bound. Political economics of the future]. Warszawa: Prószyński i S-ka.

Łaski, K. (2015). Wyktady z makroekonomii [Lectures in macroeconomics]. J. Osiatyński (Ed.). Warszawa: PTE.

Żyżyński, J. (2009). Budżet i polityka podatkowa [Budget and Tax Policy]. Warszawa: PWN.

Żyżyński, J. (2014). Pieniądz egzogeniczny jako baza dla emerytur kapitałowych [Exogenous money as the basis for capital pensions]. In: J. Czekaj \& S. Owsiak (Eds.), Finanse w rozwoju gospodarczym $i$ spotecznym [Finance in economic and social development]. Warszawa: PWE. 